University of Louisville

ThinkIR: The University of Louisville's Institutional Repository

Electronic Theses and Dissertations

$12-2012$

\title{
Albert Taylor Bledsoe : Whig intellectual and proslavery theorist.
}

Lori Jean Wilson 1974-

University of Louisville

Follow this and additional works at: https://ir.library.louisville.edu/etd

\section{Recommended Citation}

Wilson, Lori Jean 1974-, "Albert Taylor Bledsoe : Whig intellectual and proslavery theorist." (2012). Electronic Theses and Dissertations. Paper 1582.

https://doi.org/10.18297/etd/1582

This Master's Thesis is brought to you for free and open access by ThinkIR: The University of Louisville's Institutional Repository. It has been accepted for inclusion in Electronic Theses and Dissertations by an authorized administrator of ThinkIR: The University of Louisville's Institutional Repository. This title appears here courtesy of the author, who has retained all other copyrights. For more information, please contact thinkir@louisville.edu. 


\title{
ALBERT TAYLOR BLEDSOE: WHIG INTELLECTUAL AND PROSLAVERY THEORIST
}

\author{
By \\ Lori Jean Wilson \\ B.A., California State University Los Angeles, 2010

\begin{abstract}
A Thesis
Submitted to the Faculty of the

College of Arts and Sciences of the University of Louisville in Partial Fulfillment of the Requirements

for the Degree of
\end{abstract}

Master of Arts

Department of History

University of Louisville

Louisville, Kentucky

DECEMBER 2012 
Copyright 2012 by Lori Jean Wilson

All rights reserved 
Albert Taylor Bledsoe: Whig Intellectual and Proslavery Theorist

By

Lori Jean Wilson

B.A., California State University Los Angeles, 2010

A Thesis Approved on

November 16, 2012

by the following Thesis Committee:

A. Glenn Crothers

Thesis Director

Thomas C. Mackey

Susan M. Ryan 


\section{DEDICATION}

To Gail, my first history teacher. 


\section{ACKNOWLEDGMENTS}

I would like to thank my thesis advisor, A. Glenn Crothers, for his unwavering patience, encouragement, guidance, and moral support. He consistently made himself available as a sounding board and suggested secondary source readings that became crucial to the development of this thesis. I would also like to thank the other members of my committee, Dr. Thomas Mackey and Dr. Susan Ryan for their comments and suggestions. Many thanks are also owed to my partner, Angie, who made me write even when I thought I couldn't. I am humbled by her faith in me. And, to Jacob, who reminds me daily of why education is so important, thank you. 


\begin{abstract}
ALBERT TAYLOR BLEDSOE: WHIG INTELLECTUAL AND PROSLAVERY THEORIST

Lori Jean Wilson
\end{abstract}

November 16, 2012

This thesis explores the life and career of Albert Taylor Bledsoe, a conservative Whig intellectual and proslavery theorist. It seeks to understand an apparent contradiction in Bledsoe's public comments regarding slavery and secession. Bledsoe lived in a socially and politically dynamic world. His comments on slavery must be understood in the different political contexts in which they were made. This thesis explores those contexts and illuminates Bledsoe's desire to preserve social hierarchies and maintain public order, which Bledsoe believed necessary to secure liberty and equality among white men. The same concerns informed Bledsoe's shift toward secession. Bledsoe remained a Unionist through the 1860 election, believing both the Democratic fire-eaters and the Republicans represented radicalism and threatened public order. After the election of Lincoln with only northern votes, however, Bledsoe embraced secession as the only means to preserve the racial hierarchies upon which he believed a morally ordered society was built. 


\section{TABLE OF CONTENTS}

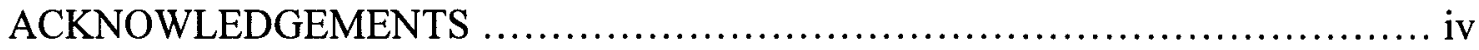

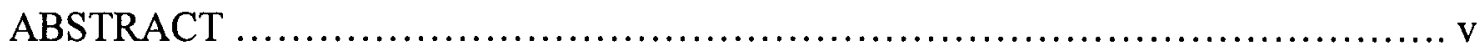

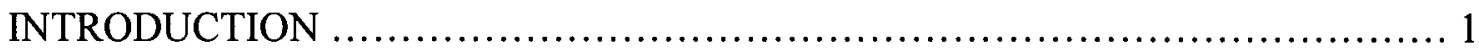

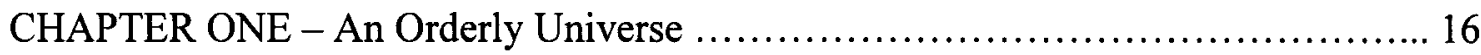

CHAPTER TWO - "The General Good" ....................................... 36

CHAPTER THREE - A More Perfect Confederation ........................... 58

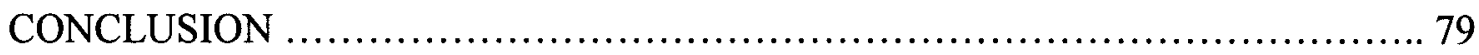

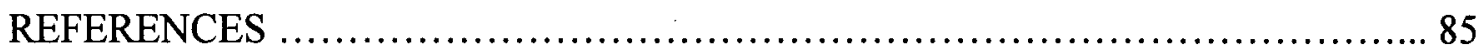

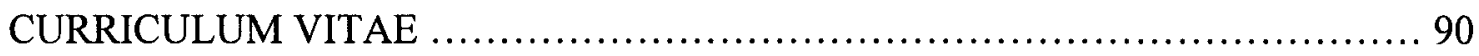




\section{INTRODUCTION}

In 1906, the Illinois State Historical Society asked Dr. Samuel Willard to write about his experiences as a young man in Illinois. Willard first came to Illinois in 1830 as a nine-year-old, when his father Julius, a school teacher, relocated from Boston and settled in Greene County. In his memoir, Willard described the cultural, economic, and technological development of central Illinois. He also recalled events that he believed important to the state's history. He discussed the cholera epidemic of 1832 and mentioned the murder of Elijah Lovejoy as a critical event in sparking his abolitionist activism. Willard's antislavery efforts also brought him in contact with two influential antebellum figures: Abraham Lincoln and Albert Taylor Bledsoe. When Willard met Lincoln and Bledsoe the two men practiced law in Springfield and played prominent roles in the Springfield Whig Party. Each man embraced Whig political, cultural, and economic values. Their individual interpretations of those Whig values propelled them in different directions in the 1850s and 1860s. Lincoln emerged as the leader of the Republican Party, while Bledsoe remained committed to a conservative Whig outlook that emphasized maintaining existing social hierarchies and preserving social order. Lincoln's path led him to the presidency, Bledsoe's to relative obscurity. Yet contemporaries like Willard believed Bledsoe the more likely of the two to be remembered by history. ${ }^{1}$

In February 1843, Willard and his father Julius aided the escape of a fugitive slave and were "indicted under the statue against harboring fugitive slaves" in Morgan 
County. The Willards knew they would likely face stiff penalties because of the unpopularity of abolitionism in central Illinois. Another abolitionist, Luther Ransom, advised them to seek counsel in Springfield where they could at least procure a "popular pleader." On arriving in the town, the Willards headed to the offices of E. D. (Edward Dickinson) Baker and Albert Taylor Bledsoe. When Baker lived in Greene County he had attended the same Campbellite Baptist church as the Willards where he had impressed them with his eloquence. Baker cited political aspirations and declined the case, as did Bledsoe. While waiting in Baker and Bledsoe's offices, Willard encountered "the gauntfaced, awkward, and long-limbed" Lincoln for the first time. He was struck by the differences between the personalities he encountered in the office that day:

Bledsoe was of a logical mind, acute, learned, versatile, able and even, powerful in any field of thought except natural science, in which he was untried. He had graduated at West Point, then taught mathematics, next studied theology and was ordained an Episcopal clergyman, but had turned to the law. Before a Supreme Court, where the humor and commonsense of Lincoln and the eloquence of Baker would have availed little, the logic of Bledsoe might have outdone [Spingfield Judge Stephen Trigg] Logan, or have adorned that bench itself.

Had one who knew the three men been told that one of the three should become the President of the United States, and were he then bidden to point him out, he would have said: "Baker is not the man. For he was born in England; besides, eloquence doesn't win. See Clay and Webster and, earlier, Fisher Ames and Pinckney. Lincoln will do for Sangamon county, or to go to Congress from this district; but if the lightning of a presidential nomination hits him, it will hit the wrong man; he has more risk of being hit by the real article. Bledsoe must be the man."

Willard lamented that Bledsoe left the law and wasted his "splendid powers in the humdrum life of the professor of mathematics in a Southern university." Willard did not offer an analysis of Bledsoe's reasons turning to the South but he believed that Bledsoe's embrace of southern institutions caused his downfall. Willard failed to consider that Bledsoe's conservative Whig thought, which emphasized the importance of social order 
based on perceived natural hierarchies, informed his rejection of northern liberalism and his embrace of southern institutions. ${ }^{2}$

In the 1840s, all three lawyers were prominent members of the Springfield Whig Party and dedicated themselves to the Whig agenda that sought both national and individual improvement. They were nationalists who believed the federal government had an important role to play in improving the lives of its citizens. They supported federal funding of internal improvements, including railroads and turnpikes. They sought a national bank to regulate national currency and provide credit. They disagreed with the Democratic Party's expansionist goals in the Mexican War because they believed the government should focus instead on underdeveloped areas that already belonged to the United States. They each embraced Whig cultural values that placed a premium on discipline, improvement, education, and reform. Lincoln and Baker, like many northern Whigs, moved into the antislavery Republican Party in the 1850s. Historians have long considered how Whig cultural values shaped the development of the Republican Party; they have paid less attention to the intellectual consistency between Whig cultural values and the antebellum South's proslavery and secessionist ideology. Bledsoe's life and career provide an opportunity to explore how a man committed in the 1830 s and 1840 s to a Whig political and cultural ideology that placed national above sectional interests could come to advocate secession in the 1860 s. $^{3}$

Social order and liberty lay at the heart of Bledsoe's Whig values. Although his political and sectional affiliations changed over the course of the antebellum era, Bledsoe remained committed to an organic view of society in which interconnected racial and gender hierarchies maintained public order and guaranteed private liberty among white 
males. His trajectory from nationalist to secessionist was a product of the evolving political landscape in which he lived. He embraced the Whig Party's nationalist cultural and economic platform in the 1840s because he believed it offered the best means of safeguarding liberty and maintaining social order. He opposed the Mexican War and the extension of slavery into the territories for similar reasons. Yet in 1856 he wrote $A n$ Essay on Liberty and Slavery, a formal defense of the South's peculiar institution. By 1861 he came to believe that the North had devolved into anarchy when it vindicated equalitarianism and the Republican Party by electing Abraham Lincoln to the presidency. Thus, he accepted secession and the Confederacy as the best means of maintaining social order and preserving liberty.

As an antebellum intellectual, Bledsoe has not received attention from historians commensurate with his contemporary influence. At Bledsoe's death on December 8, 1877 , newspapers and journals commemorated his life. Alluding to Bledsoe's intellectual reputation, the Richmond Christian Advocate cried poetically, "A giant is prone in the dust. A star of the first magnitude has gone out." As a teacher of astronomy, Bledsoe would have appreciated the metaphor. A correspondent to the Episcopal Methodist immortalized Bledsoe and his celebrated intellect in a poem entitled, "Our Dead." The opening lines spoke to Bledsoe's versatility of thought:

The wide world suffered loss when Bledsoe died. His mighty mind pierced every realm of thoughtGrappled sublimest themes, deep problems tried, And scaled vast heights which lesser minds ne'er sought.

Bledsoe had earned contemporary respect and national recognition for his prolific writing and his breadth of knowledge. But historians have overlooked Bledsoe in part because he promoted arguments - proslavery paternalism, slavery as a positive-good, and biblical 
support for slavery - that reflected orthodox thinking among southern intellectuals. To find originality in his proslavery writings one must look for subtle distinctions rather than obvious departures from prevailing contemporary proslavery thought. ${ }^{4}$

Historians have also ignored Bledsoe because the social values he espoused have since become unpopular and irrelevant. Although the racist assumptions that Bledsoe and his fellow proslavery intellectuals espoused remained a part of American life until well into the twentieth century, they have had little support since the Civil Rights movement. And his attacks on the Declaration of Independence and its basic tenets are out of step with a modern America that has seen the progressive expansion of individual rights. Moreover, those historians who have written about Bledsoe have emphasized his postwar defense of the Southern Confederacy. In so doing, they have painted a picture of Bledsoe as the quintessential unreconstructed southerner. While Bledsoe's postbellum work is important, particularly the anti-northern invectives that filled the pages of the Southern Review while he was editor, placing too much emphasis on Bledsoe's postbellum, prosouthern rhetoric distorts his intellectual career. Seeing Bledsoe as an Confederate apologist makes his antebellum proslavery study, An Essay on Liberty and Slavery, and his inquiry into the right of secession, Is Davis a Traitor?, seem more like southern propaganda and less like authentic intellectual pursuits. In reality, both books resulted from Bledsoe's efforts to make sense of the political realities around him. Understanding Bledsoe requires seeing him as a conservative Whig thinker with a particular cultural vision rather than as a man of the Old South. ${ }^{5}$

Bledsoe played a prominent role in antebellum America and the Civil War. $\mathrm{He}$ was acquainted with Robert E. Lee, Jefferson Davis, and Abraham Lincoln. Throughout 
his diverse career, he was an Episcopalian minister, a formidable lawyer, a respected professor, a journal editor, and assistant secretary of war for the Confederate States of America. Bledsoe made his greatest mark, however, with his pen. His deep religiosity and commitment to conserving a hierarchical social order remained the primary emphasis of his thought. He gained fame and respect among contemporaries for his two books on theology, An Examination of President Edwards' Inquiry into the Freedom of the Will (1845), and $A$ Theodicy (1854). However, Bledsoe did not content himself with the study of theology alone. He also addressed the most controversial issues of his day-slavery and secession. ${ }^{6}$

Born in Frankfort, Kentucky, in 1809, Bledsoe displayed a keen mind at an early age. In an 1899 biographical sketch written for the University of Virginia alumni newsletter, Bledsoe's daughter, Sophia Bledsoe Herrick, stated that as a child he exhibited "a remarkable intelligence and indomitable will, rul[ing] the family from his father down." Kentucky Congressman Robert Letcher, a life-long friend of Bledsoe's father, Moses, took an interest in Bledsoe after a visit to the Bledsoe home. Letcher brought along a rather complicated puzzle that the adolescent Bledsoe quickly solved. Bledsoe's mental prowess prompted Letcher to suggest that Moses send his son to the United States Military Academy at West Point. Moses acquiesced and Letcher began a campaign to gain admittance for the young man. On Bledsoe's application, Letcher touted the young Kentuckian as "a youth of fine promise." In 1825, at the age of fifteen, Bledsoe entered the academy, the youngest cadet ever admitted to West Point. ${ }^{7}$

The personal relationships Bledsoe developed at West Point proved as enduring as the lessons he learned as a cadet. The military school also served to reinforce the 
importance of hierarchy and discipline. While at the academy he met both Robert E. Lee and Jefferson Davis. Bledsoe and Lee entered as classmates but Bledsoe struggled academically his first year at the academy and graduated a year later than Lee. Bledsoe's daughter attributed her father's early failure at West Point to his lack of formal education. Lee and Bledsoe remained correspondents until after the Civil War, but Bledsoe's relationship with Jefferson Davis, two years ahead of Bledsoe at the academy, had a more profound influence on his life. At West Point, Bledsoe also met Episcopal minister Charles Petit McIlvaine and converted to Episcopalianism. ${ }^{8}$

After graduating sixteenth in his class of forty-two cadets in 1830 , Bledsoe served his compulsory military duty as Brevet Second Lieutenant with the $7^{\text {th }}$ Infantry at Fort Gibson in Indian Territory (Oklahoma). Bledsoe disliked the post and left the military at the earliest possible date. In 1832, after his release, Bledsoe began reading law with his maternal uncle, Samual Taylor Jr., in Richmond, Virginia. However, Mcllvaine encouraged Bledsoe to move to Ohio and take a teaching position at Kenyon College, a suggestion Bledsoe followed. Mcllvaine's influence extended beyond bringing Bledsoe into the Episcopalian fold; through Mcllvaine, Bledsoe met Harriet Coxe, Mcllvaine's sister-in-law and Bledsoe's future wife. At Kenyon, Bledsoe met Dr. William Sparrow, beginning a relationship that guided Bledsoe throughout his life. The pair took evening walks around campus debating metaphysics. During one of their walks, Sparrow challenged Bledsoe to refute Jonathan Edwards's Freedom of the Will. Bledsoe completed the task ten years later when he published An Examination of President Edwards' Inquiry into the Freedom of the Will. Sparrow's guidance instilled a sense of theological confidence in Bledsoe that remained a hallmark of his writing. ${ }^{9}$ 
In 1835, Bledsoe left Kenyon after two years and accepted a position teaching mathematics at Miami University in Oxford, Ohio. He did not remain at Oxford long, but he became acquainted with proslavery professor William Holmes McGuffey. The two became fast friends and together they opposed more liberal faculty members in a debate over student discipline. Miami University was a tumultuous place during his tenure. Like nearby Lane Seminary in Cincinnati, Ohio, Miami University witnessed growing rowdiness among the student body. Unlike Lane, however, the students never mounted a full riot. In July 1836, Bledsoe tendered his letter of resignation amid controversy, having served as professor for only nine months. In his letter of resignation, Bledsoe stated that God called him to enter the ministry, but later comments, as well as his inability to commit to the ministry, suggest that an ongoing dispute between disciplinarian faculty members such as himself and lax university administrators, such as President Robert Hamilton Bishop, led to his departure. ${ }^{10}$

Bledsoe remained deeply religious and committed to theological inquiry throughout his life, but he never settled into the role of minister. He expressed discomfort with certain tenets of the Episcopal tradition. He opposed the practice of infant baptism, and denied baptismal regeneration. In March 1837, after spending only eight months as rector at Grace Church in Sandusky, Ohio, Bledsoe accepted an assistant minister position at Christ Church in Lexington, Kentucky. Within two months of accepting the new position, tensions arose between Bishop Benjamin Bosworth Smith and himself. Bledsoe regularly voiced his objections to the tenets and practices of the church with which he disagreed. He resigned by the end of the year, accepting another short-lived position in Cincinnati. ${ }^{11}$ 
Unable to commit to the Episcopal ministry, Bledsoe moved to Greene County, Illinois, where his parents had settled in the 1820s. Initially, Bledsoe set up a law practice in Carrollton, but better opportunities soon lured him to Springfield where he became acquainted with Lincoln and Stephen Douglas. The three practiced law in the same court circuit and Lincoln and Bledsoe became friends. The Bledsoe and Lincoln families lived in the same wing of the boarding house above the Globe Tavern, and Harriet Bledsoe assisted Mary Todd Lincoln during childbirth. Sophia, Bledsoe's eldest daughter, often babysat for the Lincolns, and Bledsoe and Lincoln socialized with one another in the evenings. In addition to their personal and professional connections, the men worked together to promote the Whig political agenda in Illinois. Both men had spent their boyhood in frontier Kentucky and as residents of early national Illinois, and both believed that western prosperity required an infrastructure that would enable the state's agricultural products to reach markets in the East. Thus, they embraced the Whig Party's platform of economic improvement and wholeheartedly supported Henry Clay's "American System." Clay's plan proposed a federal tariff to make American goods competitive in the global market, a national bank and national currency, and federal monies for internal improvements. The "American System" proved popular among westerners who sought internal improvements to increase their access to national and international markets. In 1842, Bledsoe met with fellow Whigs to endorse Clay's presidential nomination in the 1844 election. The meeting resulted in the creation of the "Clay Club" of Springfield with Bledsoe and Lincoln serving as executive officers. In addition to serving as an officer in the club, Bledsoe also edited the Illinois Journal, the mouthpiece for the Whig Party. The polemical and vitriolic style he developed as a 
partisan editor testified to the highly charged political atmosphere of the 1840s and defined his intellectual efforts for the remainder of his life. ${ }^{12}$

In 1848, Bledsoe left behind a successful but not particularly lucrative legal career. He accepted a professorship of mathematics and astronomy at the newly instituted University of Mississippi in Oxford. The social atmosphere in Mississippi, where most of the faculty owned slaves, differed markedly from that of Springfield, but Bledsoe adjusted rather well. Perhaps he adapted so readily to living in a slave society because his mother had owned slaves or because he had lived briefly in Virginia in the 1830s while reading law with his uncle. But Bledsoe's decision to become a slave owner demonstrated how easily someone with an organic view of society, based on gender and racial hierarchies, could adjust to a world built on slavery. In his second year at the University of Mississippi, Bledsoe met mathematics professor and future United States Supreme Court Associate Justice Lucius Quintus Cincinnatus Lamar. Their friendship continued until Bledsoe's death in 1877. Lamar played a critical role in Mississippi's 1861 decision to secede from the Union, writing the state's ordinance of secession. In Mississippi, Bledsoe renewed his friendship with former West Point student, Jefferson Davis. Sophia Bledsoe recalled that while the family was in Mississippi, Davis visited the Bledsoe home on a number of occasions, staying several days at a time. Bledsoe's friendship with Davis proved enduring. At the outset of the Civil War, Davis appointed Bledsoe chief of the bureau of war, an appointment that a young war clerk described as a "special favor." Later, Davis appointed Bledsoe assistant secretary of war. ${ }^{13}$

In the latter years of the war, Bledsoe traveled to London to prepare a defense of southern secession. In an 1864 letter to Davis, Bledsoe wrote promisingly about his 
findings: "I have brought many hidden things to light—many things not dreamed of even by our friends; which will show the justice of our cause in new and convincing points of view." In 1866, Bledsoe finished Is Davis a Traitor; or was Secession a Constitutional Right Prior to the War of 1861 ? He bragged, and many readers accepted his assertion, that the book convinced "the Republican leaders of Washington City [to] conclud[e] to enter a nolle prosequi" in the postwar treason prosecution of Davis. Because he believed his arguments in the book unanswerable, he attributed Davis's freedom to them and did not consider the prosecutors' other motives in dismissing the case. Some of Andrew Johnson's administration feared a civil trial held in Virginia might result in an acquittal though cabinet members remained divided on the issue. ${ }^{14}$

By the time Bledsoe moved to Charlottesville, Virginia, in 1854 he had refashioned himself as a southerner. At the University of Virginia, he became chair of mathematics and publicly entered the contentious debate over slavery, publishing $A n$ Essay on Liberty and Slavery in 1856. The book criticized abolitionist interpretations of the Enlightenment ideas that inspired the Declaration of Independence, particularly notions of liberty and equality. Bledsoe asserted that abolitionists misused the rhetoric of the Declaration to stir men's passions but insisted that the institution of slavery as practiced in the South benefitted the enslaved, ensured white equality, promoted true liberty, and was sanctioned by God.

While Bledsoe had situated himself within the proslavery camp by the mid-1850s, he was not yet the "ardent secessionist" his students described in 1861. Like many former Whigs from the South, he supported John Bell, the Constitutional Union Party candidate, in the 1860 presidential election. In contrast, the most ardent proslavery southerners, 
known as fire-eaters, demanded a candidate who would firmly support the extension of slavery into the territories. They were disheartened by Democratic candidate Stephen A. Douglas's support for the concept of popular sovereignty, which left the fate of slavery in the territories up to the citizens who resided in them. Fire-eaters instead sought federal guarantees for the protection of slavery. While not an ardent secessionist in November 1860, by February 1861 Bledsoe had accepted the likelihood of secession, and by March 1861 vocally advocated disunion. In the months before the war, he mobilized students at the University of Virginia, helped form military companies of students, and gave speeches advocating disunion. When Bledsoe's students embraced secession he encouraged their efforts. ${ }^{15}$

In embracing secession and defending slavery, Bledsoe did not contradict his earlier comments regarding slavery and disunion; rather, his move toward disunion and his formal defense of slavery remained rooted in his commitment to conserving existing social hierarchies and keeping public order. Thus, his intellectual career was marked by consistency rather than contradiction. As historian Larry E. Tise points out in Proslavery: A History of the Defense of Slavery in America, 1701-1840, historians have tended to make distinctions in proslavery thought that did not exist in reality. Tise argues that strains of proslavery thought remained rather consistent throughout the antebellum era and were not exclusively southern. He refutes the contention that the "positive-good" argument was a nineteenth century innovation, finding colonial examples of its use. Tise also notes that some proslavery writers referred to the institution as "evil." Thus, while comments Bledsoe made in his early career do not appear proslavery, neither should they be considered antislavery. ${ }^{16}$ 
This thesis examines the intellectual consistency that undergirded Bledsoe's public comments about slavery and secession. Bledsoe's sectional and political allegiances shifted between the 1840 s and 1850 s, and as they changed so did his public comments regarding the institution of slavery and the desirability of disunion. Comments Bledsoe made regarding slavery and secession in the 1850 s and 1860 s contradict comments he made as a Whig Party partisan in Springfield, Illinois, in the 1840s. Nonetheless, the statements reflected Bledsoe's consistent commitment to the preservation of the social and political hierarchies that underlay his conservatism. The thesis pays close attention to how Bledsoe's religious beliefs and his adherence to Whig political philosophy shaped his thought and subsequently his public positions on slavery and secession. Chapter One examines the key influences on Bledsoe's thought: his deep religiosity; his lasting belief in the moral absolutism, benevolent paternalism, and republican virtue that undergirded Whig political culture; and his faith that the Creator of the universe and His mandates for the proper order of things could be understood through science and logic. The second chapter explores how Bledsoe's thought influenced his public comments about slavery. It demonstrates that while his ideas were shaped by geographic location and changing socio-political currents, there remained nonetheless an intellectual consistency in his comments about slavery. The final chapter discusses how Bledsoe - a man fascinated with public order and committed to constitutionalism-came to embrace and promote secession, an act that held the potential for social unrest and undermined the authority of the Constitution.

The antebellum era regularly presented challenges to Bledsoe, a conservative Whig intellectual who believed that the moral government of the universe was based on 
natural but complementary hierarchies. His studies of and comments about slavery and secession resulted from his attempt to reconcile American cultural and political change with his conservative Whig vision of order and liberty. An examination of Bledsoe's life and career provides insight into how Whig cultural values could be touted to bolster slavery and support secession. Moreover, a detailed study of the consistency of Bledsoe's thought demonstrates the adaptibility of American conservatism. Historian Patrick Allitt describes American conservatism as reactionary. Bledsoe fits this description as he responded conservatively to an era of rapid political and social change. His story is one of continuity, not change. ${ }^{17}$

1. Samuel Willard, "Personal Reminiscences of Life in Illinois: 1830 to 1850," Transactions of the Illinois State Historical Society 11 (1906): 73-87.

2. Ibid., 85-87.

3. Eric Foner, Free Soil, Free Labor, Free Men: The Ideology of the Republican Party before the Civil War (New York: Oxford University Press, 1970); Michael F. Holt, Political Parties and American Political Development: From the Age of Jackson to the Age of Lincoln (Baton Rouge: Louisiana State University Press, 1992).

4. Richmond Christian Advocate, December 13, 1877; Baltimore Episcopal Methodist, January 18, 1878;

5. Terry A. Barnhart, Albert Toylor Bledsoe: Defender of the Old South and Architect of the Lost Cause (Baton Rouge: Louisiana State University Press, 2011), 6-9; Albert Taylor Bledsoe, An Essay on Liberty and Slavery (Philadelphia: J. B. Lippincott, 1856); Albert Taylor Bledsoe, Is Davis a Traitor?; or, Was Secession a Constitutional Right Previous to the War of 1861? (Baltimore: Innes \& Co., 1866); Patrick Allitt, The Conservatives; Ideas and Personalities Throughout American History (New Haven, CT: Yale University Press, 2009), 2-3; Historians have struggled to define American conservatism, this thesis relies on Allitt's description of American conservatism as an intellectual outlook that stresses tradition and history over innovation and responds to social and political change by emphasizing the need to maintain the status quo.

6. Albert Taylor Bledsoe, An Examination of President Edwards' Inquiry into the Freedom of the Will (Philadelphia: $\mathrm{H}$. Hooker, 1845); Albert Taylor Bledsoe, A Theodicy: or Vindication of the Divine Glory as Manifested in the Constitution and Government of the Moral World (New York: Carlton \& Phillips, 1854).

7. Sophia Bledsoe Herrick, "Albert Taylor Bledsoe," The Alumni Bulletin (Charlottesville: Faculty at University of Virginia) 6, (May 1899): 1; United States Military and Naval Academies Cadet Records and Applications 1805-1908, "Register of Cadet Applicants, 1819-1867," No. 1 (1819-1827), West Point, Orange, New York.

8. Herrick, "Albert Taylor Bledsoe," 2.

9. Paula Cozort Renfro, “Albert Taylor Bledsoe," American Magazine Journalists, 1850-1900, edited by Sam G. Riley (Detroit: Gale Research, 1989), 59; Harry E. Pratt, Albert Taylor Bledsoe: Critic of Lincoln (Springfield: Illinois State Historical Society, 1934), 6. 
10. Albert Taylor Bledsoe to the Board of Trustees of Miami University, July 25, 1836, Miami University Archives; A. L. Bledsoe (Albert Taylor Bledsoe) to W. H. McGuffey, January 17, 1837, William Holmes McGuffey Family Papers, The Walter Havighurst Special Collections Library, Miami University, Digital Collections; A. T. Bledsoe to the the Trustees of Miami University, September 15, 1836, Miami University Archives; James H. Rodabaugh, "A History of Miami University From its Origin in 1845," (M. A. Thesis, Miami University, 1933).

11. Episcopal Recorder, 14, no. 52, March 25, 1837, p. 207; "Diocese of Ohio," Episcopal Recorder, 15, no. 33, November 11, 1837, p. 131; Albert Taylor Bledsoe to Harriet Coxe Bledsoe, May 8, 1837, Papers of the Bledsoe Family, 1837-1951, University of Virginia Library, Charlottesville, Va; Herrick, "Albert Taylor Bledsoe," 3.

12. Sophia Bledsoe Herrick, "Personal Recollections of My Father and Mr. Lincoln and Mr. Davis," Methodist Review Quarterly 64 (April 1915), 671; Terry A. Barnhart, "Albert Taylor Bledsoe: The Political Creed of an Illinois Whig, 1840-1848," Journal of Illinois History 3 (Spring 2000), 11.

13. Herrick, "Recollections," 671; J. B. Jones, "Dr. Albert Taylor Bledsoe in the Confederate War Department," in A Rebel War Clerk's Diary at the Confederate States Capital (Philadelphia: J. B. Lippincott, 1866), 1.

14. Albert Taylor Bledsoe to Jefferson Davis, September 21, 1864, Letters of Albert Taylor Bledsoe, 1858-1975, University of Virginia Library, Charlottesville, VA; Albert Taylor Bledsoe, "Notices of Books," Southern Review 39 (July 1876), 222; Virginia Historical Magazine 24 (1916), xxvi.

15. Bledsoe's adherence to the Whig Party was not unique as the two-party system died a slow death in the states of the Upper South. For a detailed discussion of Upper South Politics in the era of secession, see Daniel W. Crofts, Reluctant Confederates: Upper South Unionist in the Secession Crisis (Chapel Hill: The University of North Carolina Press, 1989); Albert Taylor Bledsoe to Stephen Douglas, February 16, 1861, Stephen A. Douglas Papers, Box 38, Folder 8, Special Collections Research Center, University of Chicago Library; Walter Creigh Preston to John Preston, April 29, 1861, University of Virginia Special Collections Library, Charlottesville, Va.; University of Virginia Students' Letter to the Exchange, March 22, 1861, University of Virginia Special Collections Library, Charlottesville, Va.

16. Larry E. Tise, Proslavery: A History of the Defense of Slavery in America, 1701-1840 (Athens: University of Georgia Press, 1987), 3-4, 35-36.

17. Patrick Allitt, The Conservatives, 2-3 


\section{CHAPTER ONE}

\section{AN ORDERLY UNIVERSE}

Following Albert Taylor Bledsoe's death in 1877, Baltimore publisher, W. K. Boyle reflected on Bledsoe's life and work in the Baltimore Episcopal Methodist. In his eulogy, Boyle commented that few knew of Bledsoe's "loving and generous nature" because people assumed that his polemical writing style reflected his personality. Boyle defended the polemics, arguing that Bledsoe adopted so severe an approach in his writing because "his whole career was marked by a supreme love for the truth" and an "utter hatred for error." Boyle provided an accurate assessment of Bledsoe's work. When it came to important social and political issues of his day, Bledsoe clearly thought that he stood on the side of truth and he had little patience for dissenting opinion. In his insistence on a rational God, Bledsoe resembled most nineteenth-century theologians and revivalists. Historian E. Brooks Holifield argues that southern theologians "viewed themselves as apostles of the unity of truth," who believed that a rational God ensured "the ultimate orderliness of reality." Bledsoe envisioned truth as divinely authored, logical, knowable, and above all ordered. His view of the truth resulted from an amalgamation of his understanding of religion and science and, in turn, his vision of truth informed his political philosophy. ${ }^{1}$

Born in frontier Kentucky in 1809 to Moses Owsley Bledsoe and Sophia Childress Taylor Bledsoe, Bledsoe came from pioneer stock. In 1781, his greatgrandfather, Joseph Bledsoe, along with a group of over five hundred Separate Baptists 
and slaves, moved from Spotsylvania County to the backcountry of Virginia, into an area that would become the state of Kentucky in 1792. After settling near Gilbert's Creek, the Bledsoe family played an instrumental role in the Separate Baptist Church. The church broke away from the Congregationalists of New England because of the latter church's strict adherence to the Calvinist theory of predestination. Like most Protestants, Separate Baptists believed in the inherent sinfulness of man; however, they rejected infant baptism and emphasized the individual's role in the experience of conversion. His family's association with the Separate Baptist faith may have informed Bledsoe's exploration of the inconsistency between the doctrine of predestination and human free will. Although Bledsoe rejected components of Calvinist theology, he also found fault with some of the Arminian beliefs of Baptist theology, including the idea that believers could "backslide" or experience a fall from grace. ${ }^{2}$

Bledsoe's great-grandfather and his grandfather, William M. Bledsoe, helped lead Separate Baptist congregations in early Kentucky. In contrast, Bledsoe's father, Moses, became an avowed atheist during Bledsoe's youth, though he later became a Campbellite Baptist. Still, religion filled the Bledsoe household. Bledsoe's daughter, Sophia Bledsoe Herrick, wrote that his "mother was always the dominant influence in his life; and her profound faith and practical Christianity made the deepest impression on him." Along with his deep religiosity, Bledsoe also inherited a maverick attitude toward theological matters from his mother who as a child took it upon herself independently to "stud[y] the Bible and bec[o]me a Christian." Like his mother, Bledsoe spent much of his life attempting to understand theology on his own terms. ${ }^{3}$ 
In his attempt to sort out Christian theology, Bledsoe searched for answers that were grounded in logic and made sense in an orderly universe. He conceived of a good and just God whom humankind could understand through reason, no matter how frail human reason might be in relation to an omniscient God. A professor of astronomy and mathematics, he conceived of God as the original scientist; he believed it possible to understand God and the right order of things through scientific inquiry. He rejected the argument that God purposefully obscured the true moral government of the world in order to teach humans humility. Instead, Bledsoe argued "that the more clearly the majesty and glory of the divine perfections are displayed in the constitution and government of the world, the more clearly shall we see the greatness of God and the littleness of man." He illustrated his point by contending that Newton had taught humankind the greatest lesson in humility when he discovered universal laws. Bledsoe argued that the application of Newton's laws to the entire universe showed "the almost absolute nothingness of man, when measured on the inconceivably magnificent scale of the universe." The question for Bledsoe lay not in the ability of science to reveal the truth but in the methods by which it procured the truth. In an astronomy lecture he had published at the behest of former University of Mississippi students, Bledsoe, inspired by Newton, asked, "How canst thou criticise the book of God [nature] ere thou hast learned the very alphabet [trigonometry] in which he writes his laws and fixed decrees?" But if Bledsoe envisioned God as a great scientist, he rejected the deistic notion of God as a divinity who created the world and then removed Himself from human affairs. For Bledsoe, God directed humankind through historical progress; humans had agency and played a part in the progress but He provided the ultimate framework. Most important, 
people could know God's plan and ascertain it through an understanding of both science and theology. 4

In the lecture, Bledsoe traced historical developments in astronomy because he believed that they constituted revelations from God. He criticized the ancients with the exception of Hipparchus, one of the few early astronomers to hypothesize a sun-centered solar system, for their inability to see the "true system of the world." He blamed many of the errors in astronomy on Aristotle who "did not address himself in right good earnest to study the world which God had made; but he came with his matter, and his privations, and his forms, to show how it must have been made." He argued that Galileo was a victim of "priestly domination" and "spiritual despotism" and believed that he would have better served God, humanity, and the truth if he had chosen martyrdom rather than recanting. Yet even as humankind continually failed to understand the "true system of the world," God continued to provide guidance. Bledsoe described Hven, the island off the coast of Denmark where Tycho Brahe built his noted observatory, as being designed "as if nature had intended it for an observatory." Bledsoe credited timing and God's design to Newton's genius. He argued that the two thousand years of astronomy that predated Newton set the stage. "Time is ready for a Newton now," Bledsoe asserted, "and now a Newton is vouchsafed to earth" to "comprehend the great Geometer, who planned and built the mighty fabric of the universe." Bledsoe reconsidered Alexander Pope's verse that credited Newton with shedding light on a dark world:

Nature and Nature's Law lay hid in the Night: God said, "Let Newton Be!" and all was light.

He argued, instead, that light had dawned much earlier, but the minds of Galileo, Copernicus, and Kepler only reflected it. Newton, in revealing the mathematical truth of 
the universe offered not a reflection of sunlight (Truth), but for the first time offered humanity a glimpse of direct sunlight. ${ }^{5}$

Bledsoe did not discount human ingenuity and spirit; in many ways, he conceived of himself as next in the line of great astronomers and mathematicians. In the autumn of his life and with his legacy in mind, he sat down and penned a commentary on his writing career. Of The Philosophy of Mathematics with Special Reference to the Elements of Geometry and the Infinitesimal Method, he wrote, "I know it will live after me. I know indeed, that in the opinion of the learned world, it will make an era in the history of mathematics." He praised his unpublished work, The Mechanics of the Heavens, as "a work in which all the great problems of the natural universe are solved." Because he believed that God had designed him for a particular purpose just as He had designed Newton, Bledsoe applied his mathematical and scientific principles to understanding the deity and the moral universe God created. He concluded that his greatest work was The Moral Cosmos, another piece he never finished. ${ }^{6}$

Bledsoe's conception of God as a scientific, rational, and just figure informed his theological beliefs. In his earliest work on theology, 1845's An Examination of President Edwards' Inquiry into the Freedom of the Will, Bledsoe attributed what he saw as errors in Edwards's tome to the fact that "the true intellectual system of the world is far different from that which has been constructed by the logic of President Edwards." Discovering the actual relationship between God's omniscience and the freedom of the will, Bledsoe contended, required "harmonizing the deductions of logic with the dictates of nature." Edwards upheld the doctrine of predestination which made God the author of human motives and in turn determined the choices humans made. Critics of 
predestination accused Calvinists of antinomianism, the idea that since faith alone saved souls believers had no need to perform any good works to gain salvation. Nor had they to abide by any moral code because salvation was a gift from God and could not by earned by any human agency. Bledsoe refused to believe in a moral system in which God was the author of human choices because such a system denied human accountability and opened the door to social ills. He worried about the effect Edwards's message of moral necessity had on common people, whom he believed devoid of virtue:

It will be the one thing needful to their craving and hungering appetites. Let them be made to believe that all our volitions are produced by the action and influence of motives, so that they may not be otherwise than they are; and a sense of moral obligation and responsibility will be extinguished in their breasts unless nature should prove too strong for sophistry.

Bledsoe believed that God dealt fairly with humanity and would not create a system that led to social disorder. He charged those who believed in predestination to "reconcile[e] his [Edwards's] scheme of moral necessity with the reality of virtue, with the moral agency and accountability of man, and with the purity of God." Otherwise, Bledsoe argued, the whole doctrine of predestination stood inconsistent with the reality of the natural world. ${ }^{7}$

Edwards, a leader of the First Great Awakening in eighteenth century New England, saw Calvinist theology as intellectually consistent with revivalism. He posited that revivalism—spreading the Word of God—prepared sinners to receive Grace. By the Second Great Awakening of the nineteenth century, many denominations, including Methodists and Baptists, perceived predestination and evangelicalism as intellectually antithetical. Such evangelical groups believed that individuals going through the process of conversion could rely on the assistance of the community of believers to achieve 
salvation. They insisted that conversion still consisted of an individual recognition of one's powerlessness before God, but conversions generally took place in a group setting such as a prayer or camp meeting. In her 1980 study of southern evangelicals, historian Anne C. Loveland explains that many converted after "reading accounts of the religious experience of others, or talking to converts about their experience, or seeing others converted at prayer or revival meeting," all activities that "reestablished the connection between the individual and other human beings by allowing him to see that his experience was not unique." Following conversion, she adds, people experienced "such feelings of love and concern for the religious state of others" that they felt compelled to bring them into the evangelical fold. ${ }^{8}$

In an 1835 letter to his fiancée Harriet Coxe, Bledsoe showed a similar sentiment, expressing his joy at helping his young students at Kenyon College in Gambier, Ohio, achieve salvation. "There were eighteen dear boys presently from eleven to fifteen years of age," Bledsoe recounted, "how forcibly they reminded me of the time when I first gave up my poor cold heart to the Lord Jesus." Bledsoe saw the journey toward salvation as a battle for the soul between the forces of good and evil. In the same letter he described an individual who warned "those around him not to be cheated into religion" as an agent of Satan and "debased in wickedness." Bledsoe called the man a "foul seducer" and said that he had led some off the path of righteousness by "assuring them that he has found it [religion] by his own experience." Bledsoe viewed such presumptions as heretical. He believed that God mandated people to help each other toward salvation. "How mysterious," he wrote, are the ways of Providence that we should be so intimately and wonderfully connected ... that even the salvation of our souls is made to depend on each 
other!" Bledsoe saw this metaphysical truth reflected in the fact that "we must depend upon each other for our happiness in this life." Like other evangelicals, Bledsoe saw part of his Christian duty as creating a good and orderly society by assisting others to reach salvation. His characterization of the conversion experience placed him at the nexus between the world of conscience and the world of honor. On the one hand he viewed conversion as a deeply personal experience, brought about through an individual relationship with the Almighty. Yet in order for repentant sinners to enjoy fully the fruits of conversion they must rely on the support of the religious community. ${ }^{9}$

Bledsoe viewed the religious and secular communities as intimately linked and comparable in purpose: they were organically connected entities that shared a common goal of creating a moral and godly society. He shared the millenarian goals of most evangelicals and thus believed it necessary to perfect or improve American society. In The Democratization of American Christianity, historian Nathan O. Hatch argues that in the face of increased democratization, Americans of the early republic "rushed to biblical prophecy for help in understanding the troubled times that were upon them." American lives changed significantly from the 1780 s to the 1830 s. Hatch cites the breakdown of political and social deference, the separation of church and state, and the movement of settlers into the Trans-Appalachian West as dramatic shifts that forced Americans to rethink their collective experience. He argues that these changes not only had political ramifications but also had religious consequences that manifested themselves in the democratization of religion during the Second Great Awakening. The evangelical groups that participated in the Second Great Awakening shared a millenarian vision of the nation. But millenarianism fell into two broad categories, pre-millenarianism and post- 
millenarianism. The former held that Christ would return to earth and usher in a thousand years of righteous living; the latter posited that the earth would witness a millennium of Christian righteousness in preparation for the second coming of Christ and the end of the world. The majority of antebellum American evangelicals embraced post-millenarianism and thus saw in America a unique opportunity to create a godly society that would provide the catalyst for the second coming. American society, they believed, could be perfected to prepare the world for the return of Christ. For post-millenarian evangelicals, individual improvement and the eradication of social evils lay at the center of the effort to perfect society. ${ }^{10}$

Bledsoe shared the millenarian vision of most evangelicals but he never embraced what he saw as the radical and equalitarian aspects of the faith. Bledsoe's organic view of society as well as his belief in a rationally ordered universe situated him within the Whig political spectrum. In his study of Whig political culture, historian Daniel Walker Howe identifies three core components of American Whiggery: a "commitment to improvement" that required a "conscious direction of the forces of change"; a belief that morality trumped individual rights; and an insistence on the interconnectedness of "different classes, regions, and interest groups" that led Whigs to promote social harmony. In his discussion of postmillennial theology, Howe explains that "for all its moral urgency, social redemption was still a gradual and historical process for evangelicals within the Whig fold." Thus, in the 1830s and 1840s gentlemen like Bledsoe who believed in the preservation of social hierarchies and shunned equalitarian notions felt at home within the confines of American Whiggery and its embrace of postmillenarian theology. Bledsoe and men of his ilk supported the American 
Colonization Society and its efforts to transport African Americans "back" to Africa as a way to perfect American society, but shunned the more radical abolitionist movement that called for immediate emancipation and the assimilation of former slaves into American society. Throughout his career Bledsoe expressed a preference for colonization because he feared immediate emancipation would result in social chaos, posing a threat to public order and a danger to both races. In the 1840s he lauded Henry Clay for his support of colonization and in his 1856 defense of slavery, An Essay on Liberty and Slavery, Bledsoe implored: "If on the whole, the institution of slavery be a curse to the slave, we say let it be abolished; not suddenly, however, as if by a whirlwind, but by the counsels of wise, cautious, and far-seeing statesmen." To ensure public order, which in Bledsoe's view was the only way to create a godly society, slavery either had to be endured or brought to an end in a peaceable manner. ${ }^{11}$

No extant record exists of Bledsoe's political involvement before his move to Springfield, Illinois, in 1838. However, he embodied Whig behaviors and values at an early age. Howe notes that while Whigs came from different regional, economic, and religious backgrounds, they shared a distinct personality type that centered on "devotion to productivity, equanimity, discipline, and improvement." Already as a teenage cadet at West Point, Bledsoe exhibited these Whig characteristics. Following his initial failure during his first year at the military academy, Bledsoe buckled down, committed himself to his studies, and developed "the greatest contempt for careless or slovenly work." His discipline in regard to financial resources matched his academic efforts. Each cadet was allotted a meager salary while at the academy. While some of his fellow cadets spent their allowance frivolously and then relied, against regulations, on relatives to provide 
extra money, Bledsoe not only used his allowance responsibly but also "sent home every year a large part of the allowance." His mother boasted that "he had never for a moment been dependent upon his parents after he was fifteen, but, on the contrary, had assisted in their support from that time." Bledsoe's early life and career, then, was marked by Whig characteristics and he clung to those principles long after the death of the Whig Party in the 1850 s. $^{12}$

Bledsoe's belief in an orderly universe bolstered his faith in natural hierarchies and fed his paternalistic view of the student-teacher relationship. He took his position as professor seriously. He believed rigid discipline necessary for molding virtuous Christian citizens and ensuring social order. Shortly after Bledsoe's arrival at Miami University in Oxford, Ohio, in 1835, he entered into the ongoing conflict over student discipline. Several rambunctious students who had engaged in fights and riots faced disciplinary measures. Some of the faculty members, including William Holmes McGuffey, believed the infractions serious enough to warrant expulsion. University President Robert Hamilton Bishop, however, suggested a more lenient response. In part, Bishop was responding to pressure from the board of trustees to avoid offending the students. In a 1934 study of the incident, James Rodabaugh argued that Bledsoe entered the argument "under the influence of McGuffey." But he needed to do little to convince Bledsoe of the need for strict discipline or that Bishop's leadership of the university threatened public order and hampered student development. Bledsoe went as far as to call for the impeachment of President Bishop. When the board of trustees failed to act as he suggested, Bledsoe submitted his letter of resignation. Although he claimed he left the position to answer the call to preach, letters he wrote to McGuffey following his 
departure hint at the real reason for his abrupt exit. In September 1836, Bledsoe wrote, "It makes my heart bleed, when I reflect how the university is managed (it does not deserve the name of government) how many powerful influences are combined to win the young men who come to it to be educated." He also supported McGuffey's decision to leave the university and promised his former colleague that he could "do more good, either in Cin[cinnati] or in Miss[issippi] especially if you can get those to co-operate with you, who can appreciate and sustain the policy by which you would govern aliterary [sic] institution." Bledsoe believed order and discipline necessary for the betterment of students. $^{13}$

In addition to teaching his students, Bledsoe believed his mandate to improve humankind extended to the general population. In an 1835 letter to his fiancée, Bledsoe expressed delight at being chosen to give a lecture before the Franklin Institute at Miami University, "an institution" he described as designed to promote "the intellectual improvement of our citizens." He believed he had been selected because "the villagers would flock with as great eagerness to hear the new professor as they would to see a monkey." He informed Harriet that "the advancement of society is the subject I have selected for the occasion." Bledsoe viewed the lecture as an opportunity to ensure the moral improvement of Oxford's population. ${ }^{14}$

Soon after his arrival in Springfield, Bledsoe became an active participant in local Whig politics. During the 1840 presidential election, he worked alongside other Springfield Whigs to elect William Henry Harrison over incumbent Martin Van Buren. But Whigs' joy was short-lived when Harrison died soon after his inauguration. Bledsoe's eulogy for the late president, printed in the Sangamo Journal, praised Harrison 
for his commitment to human improvement through his advocacy of prison reform. He lauded Harrison's humanitarian concern for young criminals, noting that the Whig president wished to have "the more youthful offenders" removed from jails, which Bledsoe labeled "precincts of vice and corruption," and placed in "the private mansions of some virtuous family, by whose precept and example they might be led back to the path of virtue." Bledsoe admired Harrison's support for prison reform because both men, in good Whig fashion, "sought to make prison a place of redemption as well as retribution." Whig reformers did not limit their goal to punishing the offence; they also hoped to rehabilitate the criminal and make him a virtuous citizen. ${ }^{15}$

Evangelical reform movements shared this paternalistic view of benevolent reform. In the South, paternalists used the image of the virtuous citizen to justify removing children, often biracial, from the homes of their single mothers. In Unruly Women, historian Victoria Bynum argues that women who challenged the southern patriarchy faced fierce opposition because white males viewed any threat to their dominance as a challenge to the racial and gender hierarchy of the region. Thus, in order to ensure that children grew up in virtuous homes, local courts took them from their parents—sometimes single mothers and sometimes white mothers who cohabited with free African Americans-and placed them in homes with a white male head of household. In both prison reform and fostering the goal was the same: to produce citizens who would learn to live within and even promote the existing social order rather than thwart it. ${ }^{16}$

Bledsoe eventually came to see the institution of slavery as serving a similar benevolent and paternalistic function. But Bledsoe's reformer spirit was always tempered 
by his adherence to conservative Whig values that stressed order and discipline. Thus, he viewed prison reform as beneficial only to a point. Whereas in the 1840 s he saw such reform as a positive endeavor especially for young offenders, he lambasted "pseudo philanthropists and reckless reformers" who opposed "capital punishment" and "other institutions and laws which have received the sanction of both God and man." Bledsoe supported capital punishment because he viewed it as a tool that helped preserve social order. The purpose of prison reform, according to Bledsoe, was to create an environment in which prisoners capable of rehabilitation could be taught virtue and become productive citizens. ${ }^{17}$

Whig thinkers like Bledsoe placed so much emphasis on the concept of virtue because they believed it essential in maintaining a republican government. They assumed that only virtuous citizens could put aside their own selfish political and economic motives to make informed decisions that would benefit the entire nation. Because political thinkers in the early republic argued that property ownership guaranteed virtue, states included property restrictions for voting. Over the course of the first quarter of the nineteenth century, however, the electorate grew as men challenged the voting requirements in their various districts and states. The Democratic Party spearheaded the drive to lower property requirements for voting and the election of Andrew Jackson to the presidency in 1828 represented for his supporters the triumph of the common white man. Once in office, Jackson and his party continued to support and promote universal white male suffrage, calling into question the relationship between property and politics. By the 1830s, all American politicians accepted the reality of an expanded electorate. The Whig Party developed out of opposition to Jackson's policies in the 1830s but even Whigs 
realized that electoral success meant rethinking older notions of republican virtue. The democratization of American politics thus sparked a reassessment of the concept of virtue which was now vested in all white, male citizens. Still, conservative Whigs like Bledsoe remained fearful that political demagogues could easily mislead the masses and they continued to embrace an organic view of society that upheld older ideas of social deference even in the face of the political equality of white men. Whig thinkers like Bledsoe tied virtue to morality, intellect, and the ability to put the commonweal above one's own economic and political interests. And the Whig Party presented itself to the voters as the party of virtue, republican equality, order, and sobriety against a Democratic Party that Whigs identified as the party of vice, corruption, despotism, and demagoguery. ${ }^{18}$

In the 1840 presidential election Whigs put their faith in William Henry Harrison to restore orderly and constitutional government. Harrison ran on a platform that included promises to serve only one term, to keep executive power in check, and to end the spoils system overseen by Andrew Jackson and Martin Van Buren. Whigs charged that Democrats subverted popular sovereignty by appealing to the masses in order to get elected but then acted like monarchial despots after ascending to office. They decried Jackson's appointment of Democrats to federal offices and his pet banks as the worst kind of corruption, arguing that the Democratic leadership sought to enrich itself at the expense of the American public. Historian Sean Wilentz argues that Whigs saw the contest in moral as well as political terms, a war "between the righteous and the unrighteous." For Whig thinkers like Bledsoe, Jacksonian policies that increased executive power looked like a return to monarchial despotism, threatened public order, 
and represented a move away from millennial progress. Equally, Whigs believed that in manipulating the masses, Democrats subverted republican virtue, appealing to special interests and base passions. ${ }^{19}$

Despite democratization, the new conception of republican virtue continued to exclude free African Americans and women from citizenship because, politicians and voters agreed, they lacked the intellectual capacity to vote. They justified such exclusion in part by using what nineteenth century philosophers called "faculty psychology." Daniel Walker Howe argues that faculty psychology was the main element in the moral philosophy that defined Whig political values. The concept held that human ability could be measured on a hierarchal scale with reflexive impulses at the bottom, followed by animal or instinctive impulses. Rational power sat at the top of the scale, and only the most virtuous could control all of their impulses. Faculty psychology coupled with racist ideology labeled free and enslaved African Americans as improvident and guided by their baser instincts, and thus undeserving of a political presence. Bledsoe utilized the rhetoric of faculty psychology in An Essay on Liberty and Slavery when he claimed that "the abolitionists do not hold their passions in subject to reason." He believed that abolitionists erroneously interpreted the Declaration of Independence and put forth a vision of equality and liberty that posed a danger to society because it threatened longestablished social hierarchies. He warned that abolitionists "inflame the minds of men with the idea that they are struggling and contending for liberty, when, in reality, they may be only struggling and contending for the gratification of their malignant passions. ${ }^{, 20}$ 
Bledsoe's reasons for fearing those "malignant passions" also centered around faculty psychology. He charged that abolitionists ignored how "the institution of slavery is designed by the South, not for the enlightened and the free, but only for the ignorant and the debased." He believed that giving the vote to African Americans would be comparable to allowing the "mentally inept" to vote. Pointing to what he perceived as inherent differences between Europeans and Africans, Bledsoe argued, "There is a difference between a Hottentot and a Newton. The first should no more be condemned to astronomical calculations and discoveries than the last should be required to follow a plough." Assuming that African Americans could not control their baser instincts, Bledsoe concluded that they could not become intellectual contributors to society. But as Howe points out, race was not the only factor that determined whether a group could control their faculties. Conservative Whigs deemed Democrats, Masons, Catholics, and immigrants as devoid of virtue because of their presumed inability to control their baser instincts. Antislavery Whigs even used faculty psychology to characterize slaveholders as "licentious, lazy, and tempestuous." Ironically, slaveholders used those same adjectives to describe the enslaved. Bledsoe's ideology assumed the inherent inequality of the races and posited that only those who could balance their faculties could understand republican virtue. Thus, he concluded that freedom and suffrage for African Americans represented the worst kind of threat to public order: an ignorant electorate that could be manipulated to vote according to their special interests or base passions. ${ }^{21}$

Just as Bledsoe held fast to an understanding of virtue that excluded African Americans and women from the electorate, other Whig reformers employed Whig beliefs in the gradual improvement of society to advocate abolitionism and women's rights. 
Abolitionism dovetailed with the Whig vision of history which assumed a "gradual improvement of the human condition ... increasing political liberty, increasing power over nature, higher moral standards, and a richer quality of life." Whigs also believed that God directed history and human progress. Bledsoe shared these Whig political values to a point. He accepted that God directed human progress and was a just, good, and rational deity who promoted order over chaos. As a result, Bledsoe could not abide what he perceived as radical measures such as abolitionism and women's rights. But he also believed that God had created the races and the sexes inherently different and he saw any threat to the divine order of things as a threat to the commonweal. Thus, Bledsoe differed from members of his party who promoted radical measures in the name of human progress, concluding instead that God intended social hierarchies to stay in place and that any subversion of them threatened the stability of the moral world. ${ }^{22}$

The outcome of the Civil War only intensified Bledsoe's organic view of society. In 1871, as editor of the Southern Review he lamented that "we now see recently emancipated slaves-utterly ignorant and wholly unfit for such duties-in our legislative halls, in the highest judicial offices of some of the Southern States, and on boards of trustees as the conservators and guardians of the interests of the higher education." He also feared the woman's suffrage movement and pointed to the Roman Republic as a cautionary tale. Although he doubted that women would ever gain the right to vote, Bledsoe warned that the movement posed a danger because women might gain expanded rights. He argued that the the increase in women's rights contributed to the fall of Rome. In particular, when Rome allowed women to seek divorce it undermined the traditional patriarchal family structure that undergirded Roman society. Those who campaigned for 
women's suffrage in the United States, Bledsoe asserted, did so from an erroneous belief that men and women were created equal. Invoking separate spheres ideology, Bledsoe declared, "Everything which God has made is beautiful in its own place and season... we are, for our part, satisfied with the world as God made it without feeling the least desire to revise or correct the moral code of the universe. 23

Bledsoe spent his life attempting to understand and uphold what he saw as the true moral code of the universe. His strict disciplinarianism at Miami University, his political activism in the Springfield Whig Party, his defense of slavery as a paternalistic institution, his endorsement of secession, and his comments on women's suffrage reflected his belief that liberty and order could only be maintained if humans constructed their societies in a way that comported with racial and gender hierarchies. In Cosmos Crumbling, historian Robert H.Abzug explores how religion inspired antebellum reform movements. He argues that antebellum reformers saw the sacred and the profane as intimately intertwined and understood their reform efforts as part of a larger cosmic struggle. Like Abzug's reformers, Bledsoe imbued the struggle to maintain social order and liberty with apocalyptic meaning. In the face of American democratization and the erosion of social hierarchy, however, Bledsoe feared his cosmos was crumbling. ${ }^{24}$

1. W. K. Boyle, "Death of Rev. A.T. B., LL.D.," Baltimore Episcopal Methodist, December 15, 1877; E. Brooks Holifield, The Gentlemen Theologians: American Theology in Southern Culture, 1795-1860 (Durham, NC: Duke University Press, 1978 ), 3-4.

2. J. H. Spencer, The History of Kentucky Baptists from 1769 to 1885, Vol. 1 (Cincinnati: J. H. Spencer, 1886), 41; Willard Murrell Hays, "Polemics and Philosophy: A Biography of Albert Taylor Bledsoe" (PhD diss., University of Tennessee, 1971 ), 6.

3. Samuel Willard, "Personal Reminiscences of Life in Illinois-1830-1850," Transactions of the Illinois State Historical Society 11 (1906): 84-85; Sophia Bledsoe Herrick, "Personal Recollections of My Father and Mr. Lincoln and Mr. Davis," Methodist Review Quarterly 64 (April 1915), 665-66.

4. Albert Taylor Bledsoe, $A$ Theodicy: Or Vindication of the Divine Glory as Manifested in the Constitution and Government of the Moral World (New York: Carlton and Porter, 1856), 19-20; Albert Taylor Bledsoe, A Brief Sketch of the Rise and Progress of Astronomy in Three Lectures (Philadelphia: King \& Baird Printers, 1854), 10-14. 
5. Bledsoe, Brief Sketch, 10-14, 18, 29-32, 48-52.; Alexander Pope, "Epitaph on Sir Isaac Newton," 1730, printed in The Poems of Alexander Pope: A Reduced Version of the Twickenham Text, ed. John Butt (New Haven, CT: Yale University Press, 1963), 808.

6. Albert Taylor Bledsoe Notebooks, 1863-67, ante 1877, Accession \#104-a, Special Collections, University of Virginia Library, Charlottesville, Va.

7. Albert Taylor Bledsoe, An Examination of President Edwards' Inquiry into the Freedom of the Will (Philadelphia: $\mathrm{H}$. Hooker, 1845), 10, 12, 35, 183.

8. Anne C. Loveland, Southern Evangelicals and the Social Order, 1800-1860 (Baton Rouge: Louisiana State University Press, 1980), 10-16.

9. Albert Taylor Bledsoe to Harriet Coxe, August 18, 1835, Bledsoe-Herrick Family Papers, 1750-1964, Arthur and Elizabeth Schlesinger Library on the History of American Women, Radcliff Institute, Cambridge, Massachusetts.

10. Nathan O. Hatch, The Democratization of American Christianity (New Haven, CT: Yale University Press, 1989), 6, 184-86.

11. Daniel Walker Howe, The Political Culture of the American Whigs (Chicago: University of Chicago Press, 1979), 2021, 152-53; Albert Taylor Bledsoe, An Essay on Liberty and Slavery (Philadelphia: Lippincott \& Co., 1856), 56.

12. Howe, Political Culture, 4; Sophia Bledsoe Herrick, "Albert Taylor Bledsoe," The Alumni Bulletin (University of Virginia) 6, (May 1899): 2

13. James Rodabaugh, "McGuffy: A Revised Portrait," The Oxford Criterion (Winter 1934): 57; James Rodabaugh, "A History of Miami University from its Origin to 1845" (M.A. Thesis, Miami University, 1933), 125-30.

14. Albert Taylor Bledsoe to Harriet Coxe, November 27, 1835, Bledsoe-Herrick Family Papers.

15. Albert Taylor Bledsoe, "Eulogy on the Life an Character of William Henry Harrison," Sangamo Journal, May 14, 1841.

16. Victoria E. Bynum, Unruly Women: The Politics of Social \& Sexual Control in the Old South (Chapel Hill: University of North Carolina Press, 1992), 88-105.

17. Bledsoe, An Essay on Liberty, 27.

18. Sean Wilentz, The Rise of American Democracy: Jefferson to Lincoln (New York: W. W. Norton, 2005), 40, 482-86.

19. Ibid., 486-89.

20. Howe, Political Culture, 29-31; Bledsoe, An Essay on Liberty, 21.

21. Bledsoe, An Essay on Liberty, 45, 54, 60,106

22. Howe, Political Culture, 73

23. Albert Taylor Bledsoe, "The Mission of Women," originally printed in the Southern Review (October 1871) printed as a Congressional record for the 63rd Congress, 1st session, August 18, 1913, Senate Doc. No. 163-174 (1913).

24. Robert H. Abzug, Cosmos Crumbling: American Reform and the Religious Imagination (New York: Oxford University Press, 1994). 


\section{CHAPTER TWO \\ “THE GENERAL GOOD”}

In 1856, Bledsoe published An Essay on Liberty and Slavery, a work he claimed he had spent years contemplating. Throughout the book, Bledsoe asserted that slavery as practiced in the South constituted a public or general good, invoking the positive-good argument underlying planter paternalism. The theory posited that slavery benefitted African Americans and whites equally because it had a civilizing effect on the enslaved. But his use of the terms "public good" and "general good" also reveal that Bledsoe saw the institution as a means of preserving public order. As a professor at the University of Virginia, a hotbed of proslavery rhetoric in 1856 , Bledsoe felt compelled to defend slavery as a public good because of what he perceived as abolitionist attacks on the South. In contrast, while editor of the Illinois Journal (originally the Sangamo Journal) in the late 1840 s, he had characterized slavery as "an odious and desolating system." Examining the different political contexts in which Bledsoe made his comments reveals the intellectual consistency of his seemingly contradictory comments. Throughout his life, Bledsoe remained committed to the conservation of public order and the preservation of social hierarchies, which he viewed as constantly threatened by subversive forces in society. In the 1840 s, Bledsoe viewed the breakdown of political and social deference, embodied in universal white-male suffrage and the Democratic Party, as a threat to republicanism and social order. He believed the Democratic Party consisted of demagogues who manipulated the masses and then abused their political power. By the 
$1850 \mathrm{~s}$, however, he viewed abolitionism as a much greater threat to public order, especially in border states like Virginia where it threatened to demolish slavery and the social and racial hierarchies that undergirded the institution. ${ }^{1}$

In 1839 , after spending two years trying to find a ministerial post that did not cause him internal spiritual turmoil, Bledsoe decided to forgo the ministry. He left Ohio and moved westward to central Illinois where his parents had relocated while Bledsoe attended West Point. Although his early letters reveal Whig political and cultural values, only during his stay in Illinois did Bledsoe become active in Whig politics and begin writing for publication. Initially, he settled with his wife and infant daughter in Carrollton. Within months, however, he moved to Springfield and entered into a shortlived law partnership with Jesse B. Thomas that lasted until August 1840. Bledsoe practiced solo until May 1841 when he partnered with E. D. Baker.

Springfield fostered a partisan spirit in Bledsoe. In the presidential election year of 1840 , the town buzzed with political activity. Bledsoe actively engaged in Whig politics, supporting William Henry Harrison's presidential campaign against the Democratic incumbent, Martin Van Buren. In June, the city hosted the state-wide Young Men's and Old Soldier's Convention, a two-day affair to which each county sent delegates. Bledsoe joined the Sangamon County delegation and was named assistant chief marshal of the parade held on the closing day of the convention. The Whig Party newspaper, the Sangamo Journal, noted the decorum and attentiveness of those who attended the convention, which consisted of a series of continuous speeches lasting until midnight. "Speech on speech was listened to by the crowd with undivided attention," the paper reported, "and for hours of each day the whole concourse stood upon their feet, 
listening and responding to the flood of eloquence." The paper also rejoiced that not "a single delegate or whig on the ground [was] intoxicated. Intelligence, attention, and sobriety were the distinguishing features of the crowd and their conduct." The disciplinarian in Bledsoe, no doubt, felt right at home in this atmosphere. ${ }^{2}$

The Young Men's Convention convened on Wednesday, June 3, and drafted a series of resolutions that expressed the Illinois Whig political agenda in the 1840 election. The resolutions endorsed John Tyler as vice-president, supported federal funding for the construction of the Cumberland Road, proposed that Harrison if elected should commit to a one-term presidency, lambasted the Van Buren administration's continued support of Andrew Jackson's pet banks, and charged the president with a plethora of abuses of executive power. Although the Harrison and Tyler ticket was heralded nationally as the "Log Cabin and Hard Cider" campaign, the Whigs who met in Springfield adopted a more sober slogan: "Liberty and Reform." The Sangamo Journal labeled the Whig candidates as the "Constitution and Laws" ticket. Both slogans attacked what Whigs perceived as Van Buren's abuses of executive power. ${ }^{3}$

During the presidential election, the issue of slavery and how to deal with the free black population arose. Historian William J. Cooper Jr. argues that the politics of slavery defined political life in the South. He contends that even as the political issues changed, slavery nonetheless remained the focal point around which southern politicians made their arguments. Democrats and Whigs attempted to portray their parties as a friend to slaveholding interests and as champions of the South in the national political arena. Both vehemently denied ties to antislavery or abolitionism. Cooper's study focuses exclusively on southern politics, but Springfield politicians used rhetoric and political tactics similar 
to their southern counterparts in the 1840 presidential campaign. Van Buren stressed the constitutionality of slavery and supported prohibiting the delivery of abolitionist materials through the U.S. postal service, but many of his northern opponents nonetheless tried to label him an abolitionist. ${ }^{4}$

In response to Democratic charges that painted Harrison as an abolitionist, the Sangamo Journal reported in March 1840 that Van Buren's record revealed that the president favored abolition. The paper noted that "he opposed the admission of Missouri into the Union as a Slave State-defended the rights of free negroes to vote in New York, and [said] that Congress has the constitutional right to emancipate the slaves in the District of Columbia." To refute claims that Harrison was an abolitionist, the paper detailed Harrison's record on slavery:

Gov. Harrison in a public life of about forty years, on every occasion on which he has been called to act on the question of Slavery; has invariably supported the constitutional rights of those States where slavery is permitted, and in the controversy on the admission of Missouri and Arkansas into the Union, in every vote, while in Congress, he sustained the constitutional rights of these States to establish such laws and regulations upon this subject as were deemed best by their citizens. In regard to the conduct of the Abolitionists, he has given it as his solemn opinion, that the course they are pursuing, is a violation of the Constitution.

Late 1830s and early 1840s, Springfield politics cannot be classified as the politics of slavery, in part, because economic concerns dominated the local political landscape. However, both parties strongly resisted the abolitionist label, revealing the similarities in prevailing attitudes about race and slavery in the North and South. That the Springfield Whig Party rejected abolitionism and reaffirmed racial hierarchy helps explain why Bledsoe's transition from North to South did not require a dramatic ideological shift. ${ }^{5}$ 
In addition to painting Van Buren as an abolitionist, Illinois Whigs accused him of challenging white privilege. A July issue of the Sangamo Journal reported that while Van Buren "was in favor of a property qualification for WHITES," he had initially "VOTED IN FAVOR of conferring rights of suffrage upon FREE NEGROES and Mulattoes without a property qualification." Then he had a change of heart and "voted in favor of giving FREE NEGROES and MULATTOES the right of voting, provided they were worth 250 dollars." The same article reported on a court martial trial in which two African American men testified against a white naval officer. The paper reported that "Mr. Van Buren has given his OFFICIAL SANCTION TO THE MEASURE-thus showing that Martin Van Buren is in favor of allowing FREE NEGROES and SLAVES to swear in Courts against WHITE MEN!!" This racist rhetoric reveals the antiabolitionist attitudes of Illinois Whig Party in the 1840s. Like Bledsoe, many of its members were committed to the preservation of social hierarchies they believed sustained the republic. ${ }^{6}$

Bledsoe and his fellow Illinois Whigs welcomed the outcome of the 1840 election, but President Harrison's death weeks later and John Tyler's ascension to the executive office left them deeply dismayed. Tyler soon abandoned the Whig political agenda, leading loyal Whigs to another candidate. By 1842, Springfield Whigs had formed the Clay Club to campaign on behalf of U.S. Senator and former U.S. Secretary of State, Henry Clay. Along with Abraham Lincoln, Bledsoe served as a member of the club's executive committee. At the club's first meeting, members explained that the "last veto of the President" convinced them to support Clay. On June 29, Tyler vetoed a bill that sought to "extend for a limited period the present laws for laying and collecting 
duties on imports." Western Whigs interpreted the veto as a blow to their economic interests, believing that the tariff would make western goods competitive in national and global markets. Moreover, they viewed Tyler's excessive use of the veto as a replay of Andrew Jackson and Van Buren's abuses of executive power. Tyler's presidency, the Clay Club announced, represented a threat to republicanism and to western economic interests. The club sought instead the "restoration of the Government to its original purity, and the people to their former state of prosperity." The Clay Club never addressed abolitionism because in 1842 it did not present the same threat to republicanism as Tyler's rejection of Whig political principles. ${ }^{7}$

Bledsoe left Springfield after Clay lost the 1844 presidential election. He moved to Washington D.C. and formed a law partnership with his brother-in-law, Richard S. Coxe. But, Bledsoe returned Springfield in 1847 and reentered local Whig politics, becoming co-editor of the Sangamo Journal, later the Illinois Journal. As editor of a partisan journal, he plunged into the debate over the war with Mexico. Congress had declared war on Mexico in 1846 at the insistence of Democratic President James K. Polk. The Whigs found themselves in a precarious predicament, disapproving of the war but not wanting to appear treasonous. Bledsoe saw the conflict as a threat to republicanism and accused Polk of "plung[ing] the nation into a most profitless and desolating war, in order to illustrate his own little name." Mexican aggression, Bledsoe argued, had not sparked the war, as the administration claimed, but instead it was the result of southern slaveholding Democrats' desire for territorial gain. In the pages of the Illinois Journal Bledsoe railed against Polk: "we have been fighting, neither for justice nor for honor, but for a bargain." To Bledsoe, Polk's machinations exemplified everything that was wrong 
with America's democratic politics, in which politicians devoid of virtue could manipulate special interests for political gain. ${ }^{8}$

Northern Whigs opposed the war with Mexico because they feared it would extend slavery into the territories the United States stood to gain if victorious. Northern and southern Whigs divided on the issue of slavery and thus did their best to keep it out of national politics, but the Mexican territory debate forced the issue. Like most northern Whigs, Bledsoe supported the Wilmot Proviso, a measure proposed by Democratic Congressman David Wilmot of Pennsylvania in response to President Polk's request for additional money to fight the war. The measure stipulated that Congress would appropriate war funds only if slavery was not introduced into territories gained by the war. Bledsoe never questioned the constitutionality of slavery in the states where it already existed, but he saw the provision as necessary to promote the continued political balance between northern and southern interests. He accused Secretary of State James Buchanan of using the territorial issue for political advantage, asking sarcastically if Buchanan believed the extension of slavery was "required by the great interests of freedom and humanity, or by his desire to be President of the United States?" Bledsoe pointed to Buchanan's earlier opposition to the extension of slavery and concluded that the secretary of state had "sacrificed the convictions of his own soul, when he put in his bid for southern influence." Bledsoe believed that Buchanan's changing position on slavery in the territories reflected a lack of virtue, but he did not question the morality of slavery. ${ }^{9}$

In contrast, Bledsoe's commentary on Henry Clay's position on slavery raises questions as to whether Bledsoe perceived slavery as immoral in the 1840s. In December 
1847, Bledsoe defended Clay against political opponents who claimed that the Kentucky senator pandered to antislavery interests by opposing the extension of slavery into the territories. Bledsoe claimed that Clay's position on slavery had never wavered: the senator had always supported gradual emancipation. Calling slavery an "odious and desolating system," Bledsoe concluded that Clay supported the antislavery party because "all good men belong[ed]" to that party. In the 1840s, Bledsoe, like Clay, favored gradual emancipation. He employed such strong language in Clay's defense because the senator's accusers charged Clay with demagoguery. For Bledsoe, this was the worst offence a politician could commit in a democratic society. Still, though Bledsoe used the terms "odius" and "desolating" to describe slavery, he did not deem slavery immoral. Rather, he viewed it as moral but "insufferable." His classification of Whigs as "good men" had more to do with the party's underlying principles of virtue and benevolence than the party's newly acquired antislavery label. Throughout the antebellum years Bledsoe supported the gradual emancipation of slaves, even after he relocated south of the Mason and Dixon line. Even in the pages of An Essay on Liberty and Slavery, Bledsoe presented gradual emancipation as an alternative to the immediate position of the abolitionists. Although he saw it as a last resort and doubted that it would work in practice. ${ }^{10}$

In 1848, Bledsoe left the editorship of the Illinois Journal and accepted a professorship of mathematics and astronomy at the newly instituted University of Mississippi. Although Bledsoe remained committed to the Whig Party until it dissolved, but there is little record of his political involvement in Mississippi. The comments Bledsoe made about slavery and the Wilmot Proviso prevented him from seeking a position of political leadership in the Deep South. Further, although Bledsoe was versed 
in anti-abolitionist rhetoric, he had not yet gained fluency in the politics of slavery. He could easily reject the abolitionist label but not the antislavery label, which in the Cotton South was nearly as damning as an association with abolitionism. Most important, Bledsoe did not initially own slaves, which automatically called his proslavery sympathies into question. Within two years of relocating to Oxford, however, he purchased slaves, demonstrating that politics rather than personal aversion shaped his negative comments about slavery while he was editor of the Illinois Journal. The 1850 slave schedules show that Bledsoe owned two female slaves, ages forty and four. With this purchase, Bledsoe positioned himself to enter slaveholding society. ${ }^{11}$

In Mississippi, Bledsoe found supporting slavery a political necessity. Moreover, his social ambitions rode on the backs of slaves. As historian Walter Johnson explains, slavery permeated every aspect of southern life. Although nonslaveholders benefitted from the slave economy, not owning slaves lowered their social status. Johnson argues that "for nonslaveholding white men ... buying a slave was a way of coming into their own in a society in which they were otherwise excluded from full participation." In Mississippi, Bledsoe found himself in a social setting in which full participation and social acceptance required embracing the "odious and desolating system." Bledsoe's new social circles spoke the language of slavery. While at Oxford, Bledose became acquainted with George Frederick Holmes, the president of the university. A staunch advocate of state rights and slavery and a close friend of John C. Calhoun, the South's best known defender of slavery, Holmes contributed regularly to proslavery journals and newspapers. Bledsoe also became close friends with fellow mathematics professor Lucius Quintus 
Cincinatus Lamar, a secessionist, who drafted Mississippi's Ordinance of Secession, in $1860^{12}$

Both social pressure and the need for domestic help led Bledsoe to acquire slaves. In 1915, Bledsoe's daughter, Sophia Bledsoe Herrick, reflected on her family's move to Mississippi:

The position of our family was somewhat anomalous. Every member of the faculty, as well as all the people around, owned their slaves, and we who were dependent upon hired labor had to put up with the leavings; and very poor dependences they were-usually plantation hands, entirely untrained and almost uncivilized.

Herrick added that her father was "never in entire sympathy with the idea of slavery" and her "mother was distinctly opposed to it." Still, Bledsoe is listed in the 1860 Virginia Slave Schedule as the owner of three slaves, a twenty-four year-old adult "mulatto" female, a three-year-old "black" female, and a one-year-old "mulatto" male. Herrick could not have remained oblivious to her father's slaveholder status. More likely, in 1915 she wanted to disassociate her father's memory as much as possible from the archaic institution. Indeed, she portrayed his An Essay on Liberty and Slavery not as a defense of the institution of slavery but as an attempt to solve a great social problem. ${ }^{13}$

Social pressure and personal ambition alone do not explain Bledsoe's adaptability to the slave regime. Although Bledsoe had spent the greater part of his adult life before 1848 north of the Ohio River, he nonetheless had family connections to slaveholders. His mother, Sophia Childress Taylor Bledsoe, had owned and inherited slaves. According to Herrick, his mother's attitude toward her "servants" had "a profound influence" on Bledsoe. Herrick painted her grandmother as an enlightened slaveholder who spoke fondly of her servants. Before before moving South, Herrick could not "remember ... 
ever hearing the name 'slave,' 'nigger,' or 'colored persons.'” In Herrick's portrait, her grandmother educated her servants, assigned them minimal labor, paid them for "excess" work, and allowed them to hire themselves out so that they might buy their freedom. Undoubtedly, Herrick's picture of the institution as benign and paternalistic was influenced by Bledsoe's insistence that slavery as practiced in the South was "beneficial, not to the master only, but also and especially to the slave." For Bledsoe and his daughter the institution improved slaves' earthly existence and ensured their eternal salvation. ${ }^{14}$ Bledsoe's Whiggish belief in paternalism and improvement led him to see slavery as benevolent and helped him to embrace southern society built on slavery. As Daniel Walker Howe notes, "the object of Whig didacticism was redemption: to make people better." Whigs believed they could improve society because they "assumed that human nature was malleable. It could be shaped by schools, benevolent societies, reformatories, and asylums." Bledsoe shared these Whig notions of human improvement. In 1840, he joined a committee that sought to bring a convention to Springfield for the purpose of "establish[ing] an efficient system of common schools" in Illinois. As a member of the Young Men's Christian Association (YMCA) in Virginia in the 1850s, Bledsoe continued to work toward improving society. In 1851, reformers in Boston established the first YMCA in the United States to provide sailors on shore leave a wholesome, Christian environment. Thereafter, branches opened throughout the U.S. Historian Anne C. Loveland notes that "in numerous southern cities and large towns, evangelicals gave" the YMCA "their enthusiastic support" because "they afforded young men with a means of moral religious and intellectual improvement." Loveland adds that evangelicals often participated by "teaching Bible classes, leading prayer meetings, or offering lectures." 
In 1858, Lancelot Blackford, a student at the University of Virginia formed the first YMCA on an American campus. According to historian Peter Carmichael, Virginia students in the Civil War era participated in many student-led benevolent activities in an effort to live up to the ideal of "Christian Gentleman." He argues that Blackford's "unrelenting drive for self-improvement spurred him to reform the immediate world around him." Blackford included not only his fellow students but poor whites and blacks in his reform efforts. He also worked with sympathetic university faculty, including Bledsoe, to promote benevolent reform and the YMCA. In 1857, Blackford wrote enthusiastically of a lecture Bledsoe delivered at the Lynchburg, Virginia, YMCA. For his part, Bledsoe supported the YMCA because it provided young men with opportunities for intellectual and spiritual improvement that enabled them to embody the ideal of the "Christian Gentleman." Moreover, it offered an alternative to more rambunctious and disorderly campus activities such as drinking and gambling. ${ }^{16}$

Bledsoe and other southern reformers who supported benevolent institutions like the YMCA included African Americans, enslaved and free, among those in need of improvement. YMCA leaders like Blackford extended the organization's services to African Americans and offered Sabbath Schools to slave children. By including African Americans in their efforts, southern reformers acted upon their belief that slavery in the South was a benevolent institution. In An Essay on Liberty and Slavery, Bledsoe contended that slavery was "especially" beneficial to the slave because the "Negro race [was] already so degraded as to unfit it for a state of freedom." Bledsoe believed that granting freedom to slaves would constitute an injustice because the race was "sunk so low in the scale of being that civil freedom would be a curse." In Bledsoe's eyes, the goal 
of slavery was to protect the enslaved from the "merciless impositions of the worst portions of a stronger and more sagacious race," and "to elevate" enslaved Africans "in the scale of being." Viewed from this perspective, slavery worked as an instrument of moral and intellectual improvement just like other benevolent endeavors in which Bledsoe participated. ${ }^{17}$

Assumptions about black inferiority underlay the proslavery argument and bolstered the contention that slavery was a benevolent institution. The historical development of slavery in America shaped white assumptions about black inferiority. Historian Ira Berlin argues that white Americans did not always equate slavery and race but learned to do so over time. Berlin contends that the birth of the plantation and the planter class played a key role in the transition to race-based slavery. "Novel notions of race," he notes, "accompanied the imposition of the plantation regime." Berlin describes seventeenth-century Virginia as marked by racial diversity, a time when creoles (people of mixed European and African heritages) lived alongside white Europeans and prospered. The switch to plantation agriculture and race-based slavery represented more than just a technological and economic change; it marked a shift from a society with slaves to a slave society in which the relationship between master and slave informed cultural as well as economic life. Subsequently, planters created a new racial ideology that promoted white superiority and planter paternalism. Paternalism, Berlin notes, "consigned slaves to a permanent childhood" in need of guidance and protection with masters believing they acted as benevolent fathers. White superiority, he argues, was more severe as it "demoted people of color not merely to the base of the life cycle as children, but to the base of civilization as savages." The new ideology ascribed negative 
characteristics to non-whites. Whites viewed Africans and African Americans as infantile, barbaric, lazy, and base. ${ }^{18}$

Bledsoe's writing reflected this racial ideology. He saw abolitionists as agitators who easily manipulated slaves who "possess[ed] the passions of men and the intellects of children." Bledsoe applied racial stereotypes to African Americans and concluded that because God "rendered the blessing of freedom inseparable from moral restraint" it was "vain for a people to expect to be free unless they are first willing to be virtuous." Bledsoe believed that African American slaves were controlled by their vices and passions rather than by moral restraint; denying them freedom was thus in accordance with moral law. He lamented that "the abolitionist is casting pearls before swine that can neither comprehend the nature nor enjoy the blessings of freedom." He warned his readers that "an equality of conditions, of political powers and privileges, which has no solid basis in an equality of capacity or fitness, is one of the wildest and most impracticable of all Utopian dreams. ... All order would be overthrown." "To give all men equal power where the majority is ignorant and depraved," he added, "would be indeed to establish equality, but not liberty. On the contrary, it would be to establish the most odious despotism on earth." Bledsoe's assumption of white superiority and paternalism allowed him to envision slavery as a benevolent institution that promoted the public good by ensuring that the "more sagacious" kept the "debased" race under control by uplifting the "idle and improvident" African American in the scale of civilization. ${ }^{19}$

White superiority and paternalism fit well into Whig moral philosophy. Daniel Walker Howe notes that American Whig thought was influenced by Scottish moral philosophy. He cites Adam Ferguson as a particular influence on American Whigs' 
conception of history and civilization. In the eighteenth century, Ferguson wrote $A n$ Essay on the History of Civil Society in which he described natural history as a story of progress. According to Ferguson's philosophy, God mandated progress for the natural world but engineered humans so that they were also subject to social progress. He contended that "progress in the case of man is continued to a greater extent than in that of any other animal. Not only the individual advance from infancy to manhood but the species itself from rudeness to civilization." The belief that the human race moved up the scale of civilization inspired Whig intellectuals to create models of civilization. In all such models, whites of European descent ranked at the top of the scale of civilization while African societies ranked at the bottom. Further, American Whig thinkers asserted that by replacing monarchial despotism with republicanism white American society had reached the apex of civilization, an exemplary model to which others should look. In an intellectual climate that promoted American civilization as the epitome of civilization, whites assumed their own superiority and believed paternalism represented progress. ${ }^{20}$ Although influenced by Scottish moral philosophy and its hierarchical rankings of civilizations, Whigs nonetheless emphasized culture over what they perceived as innate characteristics such as race. Howe points to Whigs' disagreement with John C. Calhoun's position that the United States should not annex territory previously claimed by Mexico because non-white Mexicans were unfit for freedom. Howe argues that the Whig ideology of improvement included non-whites and stressed that human communities shared similarities. ${ }^{21}$

As editor of the Illinois Journal during the Mexican War, Bledsoe shared and promoted the Whig ideology of human improvement. However, he doubted that blacks or 
non-white Mexicans had the ability to self-govern or understand republicanism. In September 1847, the Springfield Register, a Democratic newspaper, castigated the Whig Party as traitors and charged that Honduras, an independent republic since the 1821, lauded the American Whig Party for its support of Mexico. By linking the Whig Party to Honduras the Register attempted to make the Whig Party appear supportive of mixedrace republicanism and black suffrage. Bledsoe took umbrage at the notion that Whigs sought political support from Honduras in its stance against war with Mexico. The Whig Party, he asserted, could bear such a charge from the "President of the Negroes of Honduras" or "from the negroes of all foreign countries; because they have neither the right nor the capacity to judge our motives." But Bledsoe expressed outrage that the Democrats suggested such an alliance. Even as he feared war with Mexico would extend slavery, Bledsoe nonetheless doubted that blacks possessed competence to govern or even understand free institutions. ${ }^{22}$

For Bledsoe, the Whig hierarchy of cultures and civilizations lay in part on innate and race-specific characteristics. While he continued to claim that Americans of African descent could be uplifted through institutions of improvement, he also concluded that their progress would be slow. Moreover, he believed the two races could live peacefully together in a republic only if the wiser race provided the degraded race temporal and spiritual instruction. He expressed his disdain for mixed-race republicanism most succinctly in An Essay on Liberty and Slavery when he warned that without slavery, societies marked by a "heterogeneous population" like the South would find it "impossible to maintain either a sound public order or a decent private liberty." In Bledsoe's estimation, slavery minimized racial conflict and ensured the general good. ${ }^{23}$ 
But slavery, Bledsoe argued, could protect and uplift the slave only if Christian masters were entrusted with teaching the scripture to the enslaved. He contended that masters were obligated to ensure that their slaves received Christian instruction, and stressed that slaves be reminded of the biblical mandate to obey their masters. Bledsoe feared what he perceived as the incendiary message of liberty and equality promoted by abolitionists. He warned that abolitionists who advocated slave literacy constituted "a conspiracy against the good order, the security, the morals, and against the very lives of both the white and the black men of the South." He called for the destruction of abolitionist publications to ensure that no conspiracies, insurrections, or murders could be planned. Although large-scale slave insurrections in the South were uncommon, white southerners nonetheless remained wary of the possibility. They had only to look back to the Nat Turner rebellion of 1831 , in which the enslaved preacher Turner had led a group of slaves in an uprising that resulted in the death of sixty white residents of Southampton, Virginia including Turner's owner. ${ }^{24}$

Historian Charles F. Irons points to the Turner rebellion as crucial in the development of proslavery Christianity. Irons argues that before the Turner rebellion, white Virginians allowed the enslaved community to practice and teach Christianity with little interference. Whites showed more concern about the presence of free blacks whom whites perceived as a subversive presence and most likely to foment a rebellion. Following the Turner rebellion, however, white Virginians took control of teaching Christianity to ensure that the message of obedience reached the enslaved. The rebellion, Irons adds, opened white Virginians' eyes to the "revolutionary potential of slave Christianity." Bledsoe feared that the abolitionists' message would spark another slave 
rebellion because of their emphasis on "the Declaration of Independence rather than from the Bible," and their contention that "resistance" rather than "submission is a duty," was the enslaved's lot. Bledsoe suggested that the South would gladly promote slave literacy "if the slave would only read his Bible," "drink its very Spirit in," and understand that his duty lay in "obedience, fidelity, submission, and respect to their masters." In Bledsoe's estimation, abolitionist agitators stirred the black masses without concerning themselves with the "intellectual and moral nature of the those whom they [we]re bound to elevate in the scale of being." By playing on the passions of slaves, abolitionists threatened public order and the welfare of the enslaved. ${ }^{25}$

By threatening public order, moreover, abolitionists subverted the will of God. Bledsoe argued that the Bible sanctioned slavery and that "the institution of slavery, as it exists among us at the South, is founded in political justice, is in accordance with the will of God and the designs of his providence, and is conducive to the highest, purest, best interests of mankind." By using the phrase "designs of his providence" Bledsoe implied that God had designed a world in which slavery was necessary. This contention challenged abolitionists who regarded slavery as a universal wrong and believed that it should be abolished immediately and everywhere that it existed. According to Bledsoe, the Bible's sanction of slavery proved that it could not be universally immoral. "We only contend for slavery in certain cases," he asserted. "In opposition to the thesis of the abolitionist," he stressed, "the institution is not always and everywhere wrong." $\mathrm{He}$ accused abolitionists of "setting aside the word of God" when they insisted that slavery was always immoral and called for universal abolition. ${ }^{26}$ 
By the time Bledsoe published his proslavery apology in 1856 , the charge that abolitionists had forsaken the Bible had become common. Historian Mark Noll concludes that by the end of the American Revolution a distinctly American theology had arisen, one that incorporated Protestant religious belief, republican ideology, and the Scottish common sense moral philosophy. The Bible represented the central authority in American theology and could not be wrong, American theologians agreed, because it represented the revealed word of God. Slavery clearly appeared in the Bible, making it difficult for abolitionists to use a literal interpretation to support their cause. In response, abolitionists argued that believers should follow the spirit rather than the word of the Bible. The spirit of the Bible, they contended, did not condone slavery, even if the word had supported it in certain historical circumstances. Instead, the Bible promoted a love of one's fellow man that made slavery immoral. For abolitionists, the Golden Rule encapsulated the spirit of the Bible and damned slavery. Those who followed this mandate from Christ, abolitionists concluded, could not own slaves because no one would choose to be enslaved. ${ }^{27}$

Proslavery apologists, in contrast, embraced a literal interpretation of the Bible that gave them an advantage in the debate over whether God sanctioned slavery. Pointing to the Old Testament, Bledsoe argued that God sanctioned slavery when he commanded Abraham to circumcise his slaves in the original covenant between God and Abraham. Mosaic laws, Bledsoe continued, "contain a multitude of minute directions" for the regulation of slavery. He cited Leviticus 25:45-46 which directed Israelites to take slaves from non-Hebrews and condoned perpetual enslavement by allowing the inheritance of slaves. Bledsoe added that the mandate to love one another was not exclusive to Christ 
but that it also appeared in the Old Testament. Leviticus, the same book that mandated and condoned perpetual slavery, commanded, "Thou shalt love thy neighbor as thyself." Bledsoe contended that abolitionists wrongly interpreted the Golden Rule. Instead of asking what one "might wish or desire if placed in the situation of another," Bledsoe argued that the proper question was "what we ought to wish or desire." Because Bledsoe assumed the moral universe was based on natural hierarchies, he believed that each individual should as to be treated with fairness per their station in life. Abolitionists, he asserted, needed to consider the perceived differences between the races when they applied the Golden Rule. Freeing slaves would endanger the enslaved because they lacked the virtue, industriousness, and intellect to live as free citizens in a republic. Thus, enslaving and uplifting the slaves, he surmised, represented the best way to honor the Golden Rule. Any other interpretation, Bledsoe believed, would result in social chaos. Indeed, if abolitionists' interpretation of the Golden Rule "were correct, then the child might be set free from the authority of the father, and the criminal from the sentence of the judge. All justice would be extinguished, all order overthrown, and boundless confusion introduced into the affairs of man." The spirit of the Bible, Bledsoe concluded, did not promote universal equality but required an understanding of the hierarchically arranged moral universe. The enslavement of African Americans represented simply one natural hierarchy that held American society together. To undermine the institution, Bledsoe averred, would threaten the social fabric of the nation. ${ }^{28}$

Throughout his life, Bledsoe's deep conviction that God had created an orderly universe built upon natural hierarchies informed his political views. He believed that American political systems should reflect the moral universe. Whig cultural values that 
stressed order, discipline, and progress attracted Bledsoe. In the 1840 s he gained local notoriety for his work with the Springfield, Illinois, Whig Party. As the editor of the Illinois Journal, he became the voice of the party. Although comments regarding slavery that he made as editor of the Illinois Journal seem to contradict his postbellum image as a defender of slavery and promoter of the Lost Cause, a closer look at the political context of his public comments about slavery reveals a consistent conservative outlook. In the 1840 s, Bledsoe equated the extension of slavery with the Mexican War and the Democratic Party's expansionist agenda. He opposed expansion because, like other Illinois Whigs, he thought it more important to promote development within the United States than expand slavery. But in a departure from most Whigs, Bledsoe also opposed the war because he feared it would result in mixed-race republicanism and social chaos. Thus, in the 1840s Bledsoe saw the Democratic leadership, whom he believed used demagoguery to manipulate the newly enfranchised white masses in order to drum up support for their expansionist goals, as the greatest threat to social order.

Bledsoe's move to the South and the rise of the abolitionist movement placed slavery at the center of his political world. He came to see the institution in benevolent terms and embraced it as a mechanism for preserving republican liberty. For Bledsoe, those who attacked slavery threatened the very foundations of society. In 1856 , he defended the institution on both political and religious terms. He continued to support the Whig Party in Virginia even after the party disbanded nationally and he continued to place faith in the decades-long tradition of compromise between the free and slave states. With Abraham Lincoln's election to the presidency with only northern votes, however, Bledsoe recognized a new threat to social order and he moved toward secession. 
1. Albert Taylor Bledsoe, An Essay on Liberty and Slavery (Philadelphia: J. B. Lippincott, 1856); Sangamon Journal, December 9, 1847.

2 "Young Men and Old Soldier's Convention!" Sangamo Journal, May 22, 1840; "Out Pouring of the People: Young Men's Convention and Old Soldier's Meeting," Sangamo Journal, June 5, 1840.

3. Sangamo Journal, June 5, 1840.

4. William J. Cooper Jr., The South and the Politics of Slavery, 1828-1856 (Baton Rouge: Louisiana State University Press, 1978), xi-xii; “Van Buren Electioneering," Sangamo Journal, March 13, 1840

5. "Van Buren Electioneering," Sangamo Journal, March 13, 1840

6. "Sketches of the Life of Mr. Van Buren," Sangamo Journal, July 10, 1840.

7. "Whig Meeting in Springfield Precinct," Sangamo Journal, July 22, 1842; John Tyler: Veto Message, June 29, 1842, in Gerhard Peters and John T. Woolley, eds., The American Presidency Project, http://www.presidency.ucsb.edu/ws/?pid=67559 (accessed October 16, 2012).

8. Illinois Journal, November 18, Ibid., December 9, 1847. Daniel Walker Howe, What Hath God Wrought: The Transformation of America 1815-1848 (New York: Oxford University Press, 2007), 796-800.

9. The Illinois Journal., October 7, 1847.

10. Ibid., December 9, 1847; Terry A. Barnhart, "The Political Creed of an Illinois Whig, 1840-1848," Journal of Illinois History 3, (Spring 2000), 23.

11. 1850 Mississippi Census, Slave Schedules; 1850 US Census, Slave Schedules.

12. Walter Johnson, Soul by Soul: Life inside the Antebellum Slave Market (Cambridge, MA: Harvard University Press, 1999), 214.

13. Sophia Bledsoe Herrick, "Personal Recollections of My Father and Mr. Lincoln and Mr. Davis," The Methodist Review Quarterly 64 (April 1915), 670-71; 1860 Virginia Census, Slave Schedule.

14. Herrick, "Personal Recollections," 671; Bledsoe, An Essay, 53, 85.

15. Daniel Walker Howe, The Political Culture of the American Whigs (Chicago: University of Chicago Press, 1979), 36; Anne C. Loveland, Southern Evangelicals and the Social Order, 1800-1860 (Baton Rouge: Louisiana State University Press, 1980), 172-73; The Sangamo Journal, November 27, 1840.

16. Peter Carmichael, The Last Generation: Young Virginians in Peace, War, and Reunion (Chapel Hill: The University of North Carolina Press, 2005), 74-79; Lancelot Blackford to his father, November 23, 1857, Blackford Family Papers, Special Collections Library, University of Virginia, Charlottesville.

17. Bledsoe, An Essay, 53, 60-61, 77, 85.

18. Ira Berlin, Many Thousands Gone: The First Two Centuries of Slavery in North America (Cambridge, MA: Harvard University Press, 1998), 98-99.

19. Bledsoe, An Essay, 41, 53, 60, 77, 85, 120, 128, 134-35, 141, 271.

20. Howe, Political Culture, 49, 73; Adam Ferguson, An Essay on the History of Civil Society (Dublin: Boulter Greirson, 1767), 2.

21. Howe, Political Culture, 38-39.

22. Illinois Journal, September 23, 1847.

23. Bledsoe, An Essay, 41.

24. Bledsoe, An Essay, 53.

25. Bledsoe, An Essay, 124-26, 174-75; Charles F. Irons, The Origins of Proslavery Christianity: White and Black Evangelicals in Colonial and Antebellum Virginia (Chapel Hill: University of North Carolina Press, 2008), 140-41.

26. Bledsoe, An Essay, 8, 79, 140

27. Mark Noll, America's God: From Jonathan Edwards to Abraham Lincoln (New York: Oxford University Press, 2002), $386-400$

28. Bledsoe, An Essay, 8, 68-78, 142-44. 


\section{CHAPTER THREE}

\section{A MORE PERFECT CONFEDERATION}

In early March 1848, Albert Bledsoe remarked in the Illinois Journal that the United States as "delivered to us by our forefathers" was "the most magnificent and beautiful structure" the world had ever seen. He warned that if liberty failed in the United States it would "not be for the want of better institutions, but for the want of better men to live under and manage them. It will be because the people, and the rulers of the people, have ceased to be animated by the spirit of liberty." His comments came in response to the revolutions in Europe and to the emergence of socialist ideas and utopian communities in the United States. In 1848, Bledsoe did not envision the events that led to the secession of eleven southern states from the Union or the establishment of the Confederate States of America. To understand how a man committed to constitutionalism and who consistently referred to himself and his fellow Whigs as true patriots came to advocate secession requires exploring why Bledsoe concluded that secession provided the best means for preserving liberty. ${ }^{1}$

Bledsoe's view of liberty remained consistent throughout the antebellum period. However, as he applied his notion of liberty to the nation's changing political realities he concluded that Americans had lost sight of the virtue necessary to maintain republican government. Bledsoe responded to the revolutions in Europe and to the emergence of 
utopian ideas in the United States by warning that the "love of liberty, and the hatred of oppression, are as distinct as light and darkness." He charged that European revolutionaries were "impatient of government" and motivated not by the spirit of liberty but by "selfish passion." He argued that they intended to replace oppression with more oppression. Bledsoe characterized the revolutionaries as tyrants and predicted their demise. Believing that maintaining the republic required natural hierarchies, he stressed that social and political equality created an environment of chaos and anarchy. $\mathrm{He}$ detested the revolutions in Europe and the social philosophies that spawned them. $\mathrm{He}$ warned that the utopian "mania" that gripped various parts of the nation and sparked the creation of "new harmonies" would "end in discord" when "reduced to practice." $\mathrm{He}$ characterized Fourierism, Chartism, and "the whole swarm of isms" that swept Europe and the antebellum U.S. as "political fooleries and wild raving nonsense, and impious political trash." Throughout his life and career, Bledsoe remained critical of any movements that promoted egalitarianism. By the spring of 1861 , Bledsoe viewed secession as the only viable option for preserving his notion of liberty and the values that he believed undergirded the United States. ${ }^{2}$

Most nineteenth century Americans owed their understanding of civil liberty and republicanism to John Locke's contract theory of government outlined in the Two Treatises of Government (1689). Locke posited that in a state of perfect nature humans were born with equal rights and had the liberty to act out their will without restraint. Locke argued that because humans were ruled by reason, they willingly gave up part of their natural liberty in order to enter into peaceable society. His theory supported republicanism because he believed that humans guided by reason could be trusted to 
promote the interests of the whole of society over their own selfish desires. It influenced American revolutionaries and inspired the Declaration of Independence. In part, Locke developed his theory in opposition to the political philosophy of Thomas Hobbes. In his seminal work Leviathan (1651), Hobbes developed contract theory and introduced the idea that in a state of nature humans had the right to act according to their individual will. However, because he believed humans corrupt and selfish, he characterized natural liberty as dangerous and warned that it had to be controlled by absolute government. In An Essay on Liberty and Slavery, Bledsoe argued that Hobbes and Locke erred in their definition of natural liberty. Moreover, he charged that later philosophers perpetuated the error because they accepted the basic premise of their argument which held that natural liberty was the right to do whatever one willed. This assumption led political philosophers to conclude that government and liberty stood at odds because it restrained a portion of liberty in order to foster a peaceable society that protected property.

Bledsoe disagreed with the prevailing definition of natural liberty and thus challenged the notion that government threatened liberty. Bledsoe's deeply held belief in the rationality of God coupled with his understanding of republicanism as the pinnacle of God-guided human political progress would not allow him to embrace a view of liberty that lay at odds with God's plan for human societies. In short, he did not believe that a rational God would create humans to have natural rights that should be restrained. Bledsoe argued that the belief that a tension existed between liberty and law had caused "tremendous conflicts and struggles" that shook society and caused some of its best institutions to be "laid in the dust." He agreed that government implied restraint but insisted that government restrained the natural tyranny of humans rather than natural 
liberty. He conceded that Hobbes and Locke would have been correct in their estimation of natural liberty in an atheistic cosmos. However, in a cosmos created by God "no man possesses a natural right to do mischief so the law which forbids it does not diminish the natural liberty of mankind. The law which forbids mischief is a restraint not upon the natural liberty, but upon the natural tyranny of man." He warned that under Locke's definition of natural liberty "the sovereign will and pleasure of the individual becomes the only rule of conduct, and lawless anarchy, the condition which it legitimates." Thus, in Bledsoe's intellectual cosmos, natural law could not contradict moral law. ${ }^{3}$

Bledsoe claimed that Hobbes, Locke, and later philosophers erred in part because they failed to distinguish between liberty and rights. Liberty and natural rights, he argued, originated from different sources. According to Bledsoe, God gave humans their natural rights "and all the powers of earth combined cannot take them away." In contrast, "the sacred bonds of civil society" granted humans their liberty. Thus, he argued that natural rights were inalienable while liberties were granted by society and depended upon manmade institutions. Further, he posited that life and freedom were not inalienable rights because in certain circumstances the government could lawfully and morally deprive an individual of either. Believing that the rights of the individual stood subordinate to the rights of the community, he concluded that the state could justifiably deny life or liberty to members of society so long as doing so promoted and protected the general good. ${ }^{4}$

Bledsoe accused abolitionists of error when they labeled the Declaration of Independence an equalitarian document. He warned that the maxim "all men are created equal" did not mean "that all men have, by nature an equal right to political power or to 
posts of honor." If that were the case, he remarked, the president could be chosen by lottery. He contended that differences between individuals and between races had to be taken into consideration because "an appeal to the absolute equality of all men is the most ready way to effect the ruin of the States." While equality as an abstract principle was a "standard toward which an approximation may be made," society's goal of political inclusivity should nonetheless be "always limited and controlled by the public good." Bledsoe's stance on political equality encapsulated his conservative Whig values. He believed in the progressive march of human history and in the abstract ideal that human equality could someday be achieved. Until that day arrived, however, the public good necessitated depriving some groups of their political voice. ${ }^{5}$

Still, Bledsoe saw government as a natural right for all humans because "no greater want is known to man .... than the restraints of law and government." But one type of government would not work for all peoples. Although all people had a right to government, they did not have a right to "the same laws and government." Bledsoe's deep faith in a hierarchical civilization led him to claim that "the same government is not best for all. A despotism is best for some; a limited monarchy is best for others; while, for a third people, a representative republic is the best form of government." Although he offered this political theory in his 1856 defense of slavery, the intellectual underpinnings of his view appeared in his comments in the $1840 \mathrm{~s}$ as the editor of the Illinois Journal. ${ }^{6}$ Like most northern Whigs, Bledsoe opposed the Mexican War on grounds that it had been entered into unjustly and because he feared the expansion of slavery into territories gained from the war would increase the power of the slave states in Congress. Soon after the war ended, a new conflict emerged over how much Mexican territory the 
United States would acquire. Many Whigs believed that President James K. Polk intended to take all of Mexico with the hope of expanding slavery and giving the slaveholding states an advantage in Congress. While northern Whigs lamented the possibility of slavery's extension into so vast a territory, some southern Whigs and John C. Calhoun expressed outrage at the possibility of including non-whites in the American body politic. They warned of the dangers of annexing any portion of Mexico, and they contended that Mexicans were not fit for republican government. Bledsoe's opposition to the annexation of Mexico reveals that he worried more about the growing strength of the slave power in the 1840 s than the "odious and desolating" system of slavery itself. ${ }^{7}$

He was concerned about the preservation of the American republic as an institution of white men rather than with the eradication of slavery. In December 1847, the Baltimore Sun reported that former president and Whig Party leader John Quincy Adams intended to declare publicly that he favored the annexation of Mexico because he believed the conditions of the land made it unfit for slave labor. In the pages of the Illinois Journal, Bledsoe expressed his disbelief that Adams would come out in favor of annexation. He concluded that if Adams backed annexation it was because the former president believed "that all of Mexico will favor the abolition of slavery; and that with this acquisition to the free power, slavery will be doomed in the United States." Bledsoe conceded that "such a policy" might succeed in giving the free states an advantage in Congress and lead to the abolition of slavery but he warned that "the annexation would bring more evils upon the country than all we suffer from slavery." Bledsoe doubted that "Mr. Adams, with all his known eccentricities of character, can possibly sustain so monstrous a project as the absorption of Mexico by the United States." For Bledsoe, 
slavery was bearable and even preferable to the inclusion of non-whites into the American Republic. Moreover, the annexation of Mexico threatened the precarious balance between the free and slave states in Congress. ${ }^{8}$

Bledsoe's 1848 move from Springfield, Illinois, to Oxford, Mississippi, to accept a teaching position at the University of Mississippi reacquainted him with his old friend from West Point, Jefferson Davis. It also introduced him to some of the South's leading defenders of slavery and to the fire-eaters, proslavery politicians who advocated secession as early as 1850 . Although Bledsoe became a slaveholder he did not imbibe the fire-eater spirit that began spreading across the Deep South. In 1854, he relocated to Charlottesville, Virginia, where he remained both proslavery and pro-union until early 1861. Bledsoe believed maintaining a balance between the slave and free interests was necessary to safeguard the republic. He admired Henry Clay and saw the Kentucky senator's compromises between the free and slave states as the embodiment of Whig values. After he moved to the South, in short, Bledsoe remained committed to the Whig Party and a position of compromise.

Although the Whigs disintegrated as a national party in 1856 , regional pockets of Whig support continued, particularly in places that claimed a middle course between the proslavery southern Democrats and the antislavery Republican Party. According to historian Daniel W. Crofts such sentiments thrived in the Upper South states of Virginia, Tennessee, and North Carolina, where two-party politics remained alive and well. Former Whigs in the Upper South merged with pro-Union Democrats to create the Opposition Party. The party's name signified their opposition to radicalism on both sides of the sectional debate, and to the southern Democrats against whom they ran. During the 
winter of 1860-1861, Upper South Unionists worked to keep their states in the Union and embraced secession only when they concluded that Lincoln, in his April 15, 1861 call for troops, had abandoned efforts for a peaceful reunion. Crofts argues that until Lincoln's proclamation, Unionists remained optimistic that the nation could be preserved because "an undoubted majority of Americans preferred the center to hold and expected it to do so." Moreover, both "northerners and southerners believed that sectional differences were negotiable." Historian William A. Link argues that the second-party system remained vibrant in the Old Dominion until the Civil War. Thus, even as the second-party system collapsed nationally, in part because northern and southern Whigs could not agree on the future of slavery, Bledsoe and other southern Unionists continued to promote compromise. ${ }^{9}$

Crofts notes that unionist Whigs attempted to work across sectional and partisan lines to create a "United Opposition" that included Republicans. But John Brown's raid on Harper's Ferry spelled doom for such an alliance, driving "a wedge through the already tentative and fragile Opposition-Republican coalition" and helping "to intensify the sectional polarization that soon tore the Democratic party and the Union apart." John Brown embodied Bledsoe's deepest fears. To Bledsoe, Brown's quest for absolute equalitarianism led him to commit acts of grave violence in the name of liberty. Crofts argues that Harpers Ferry and the North's response to Brown caused many southerners to doubt not only the motives of "Black Republicans" but to question the sympathies of the northern masses. Crofts notes that "few northerners actually defended what Brown had done, but growing numbers expressed admiration for his pure motive, his courage, and his willingness to die for his beliefs." In An Essay on Liberty and Slavery, published in 
1856, Bledsoe demonstrated no ill-will toward northerners and carefully distinguished between the South's "accusers" and "the great body of the people of the North." Northerners' reaction to Harper's Ferry forced Bledsoe to reevaluate his assumption that most of them believed slavery should continue in states where it already existed. He wondered instead if northerners had joined the ranks of the French who "care but little for liberty, while they are crazy for equality." As a cross-sectional alliance became improbable, Unionist Whigs like Bledsoe looked for more viable alternatives for preserving the Union. ${ }^{10}$

In 1860, a group of Opposition Whigs seeking a middle road between the northern Republicans and southern Democrats formed the Constitutional Union Party and nominated Tennessee slaveholding congressman John Bell for the presidency. To balance the ticket, they promoted Edward Everett of Massachusetts as the vice-presidential candidate. Constitutional Union Party members hoped they could take advantage of fractures within the Democratic Party or at least force Congress to decide the election. Bledsoe joined the Constitutional Union Party and cast his vote for Bell in the 1860 election. The party attracted him because it promoted the status quo. Party members sought to preserve the Union, protect slavery where it presently existed, and maintain the balance of power between the slave and free powers. ${ }^{11}$

Still, Bledsoe harbored misgivings about the future of the Union, most notably in a February 1861 letter to former presidential candidate Stephen A. Douglas, in which he praised Douglas for his speech on the Kansas-Nebraska Act and assured the defeated politician that "in the eyes of posterity" the address would bring him more honor than "a thousand presidencies." Despite his support for the Constitutional Union Party, Bledsoe 
told Douglas that he had looked on Douglas's nomination at the April 1860 Democratic National Convention in Charleston, South Carolina, as the last means of preserving the Union. Bledsoe claimed that the Democratic Party's failure to nominate Douglas as the sole presidential nominee left him with "so bitter a pang." He added that Lincoln's election caused him less anxiety because after the "split" at the Democratic convention he "looked upon his [Lincoln's] election as certain." 12

Historian Sean Wilentz argues that fire-eaters went to the Charleston Convention with the purpose of thwarting Douglas's presidential hopes because they believed "if Douglas ran with the backing of southern Democrats, he might actually win the election, thereby severely setting back the secessionist cause." Fire-eaters predicted that a Lincoln victory in November would prompt the Deep South to secede, and a divided Democratic Party would ensure Lincoln's election. In April 1860, when Democrats met at Charleston to decide on a platform and choose a presidential nominee conflict arose over the slavery issue. When the northern delegates, holding a majority, adopted a plank endorsing popular sovereignty, fifty southern delegates walked out. Unable to come to a decision regarding a platform or nominee, the remaining delegates decided to reconvene in Baltimore in June. The Charleston Convention did not officially split the Democratic Party but it signified that northern and southern Democrats could not reach a compromise on the slavery issue or nominate a candidate that satisfied both northern and southern interests. At the Baltimore Convention another showdown took place between fire-eaters and Douglas supporters. Pro-Douglas men from the Deep South arrived in Baltimore anticipating they would take the seats of the fire-eating delegates who had bolted from the Charleston Convention. But the fire-eaters also showed up expecting recognition as 
delegates from their respective states. The convention voted to seat all of the delegates with the exception of the fire-eaters from Louisiana and Alabama. In response, the fireeaters balked, the majority of the southern states withdrew from the convention, and Douglas received the nomination. The anti-Douglas men reconvened in Richmond and nominated John C. Breckinridge of Kentucky for president. ${ }^{13}$

When Bell and his supporters learned there would be two Democratic nominees, they cried foul. They preferred Douglas to either Breckinridge or Lincoln, certain that the election of a sectional candidate would destroy the Union. As Daniel Crofts argues, Douglas and Bell supporters shared a mutual affinity because of their commitment to preserving the Union. Bell and his supporters concluded that the events at Charleston, Baltimore, and Richmond demonstrated a fire-eater conspiracy. Doubting Breckinridge's national appeal, they argued that his supporters did not believe their candidate could win the presidency. According to Constitutional Unionists, southern Democrats sought to peel support from Douglas, the Democratic candidate with national appeal, throw the election to Lincoln, and spark a mass exodus of southern states from the Union. To Bledsoe, the fire-eaters' political gymnastics represented an assault on republicanism. They not only threatened the balance of power between the slave and free states, but actively sought to destroy the Union with their political machinations. Only four years earlier Bledsoe had written a formal proslavery defense; his support of the Constitutional Union ticket in the spring and early summer of 1860 , suggests that he considered secession and abolition equally radical. ${ }^{14}$

As a committed Unionist, Bledsoe viewed the fire-eaters as a radical minority who posed a threat to the nation and public order. Moreover, as a proslavery unionist who 
believed that the Constitution offered the best protection for slavery, he concluded that the preservation of the Union rather than independent southern states or a southern confederacy would ensure the survival of the institution. Such proslavery unionism was common throughout the Upper South, which had witnessed constant conflict over the issue of slavery in the seventy years before the war, sometimes with deadly results. As historian Stanley Harrold argues, the borderland tension over slavery sparked a distinctive border state outlook. Proslavery men in the Upper South, Harrold notes, believed that unionism offered the best means to protect slavery because they had relied on federal intervention on their behalf throughout the antebellum period. Further, some border state slaveholders feared that secession would only increase the number of runaway slaves who could escape into an entirely different nation without the danger of being returned to their masters. ${ }^{15}$

Bledsoe remained committed to preserving the Union throughout the summer and autumn of 1860 and cast his vote for Bell and the Constitutional Union Party. However, Lincoln's election with only northern votes solidified Bledsoe's fears that the delicate balance of power between slave and free states had collapsed. With the election of Lincoln, northern politicians no longer had to pander to slave interests to win a presidential election. Lincoln, a friend and colleague of Bledsoe's in the 1840s, now symbolized the threat of "Black Republicanism." Bledsoe had campaigned for Harrison, Clay, and Tyler, spent evenings at the Globe Tavern socializing with Lincoln, and the two had tried cases against each other in the Illinois Supreme Court. In some southern circles, his former friendship with Lincoln remained a blight on Bledsoe's character. Upon Bledsoe's death in December 1877, a correspondent to the Southern States, an 
Okolona, Mississippi, newspaper, defended Bledsoe against the charge that he had been Lincoln's "bosom friend." The correspondent characterized the two men as "antipodes," saying that "Bledsoe was a Christian, Lincoln a blasphemer of the Most High. Bledsoe was a patriot; Lincoln a sectional partisan; Bledsoe was a scholar; Lincoln an unrefined churl." Any warmth Bledsoe felt for Lincoln in the 1840s had evaporated by November 1860. As a member of the Constitutional Union Party, Bledsoe was certain that Lincoln's election would spark the secession of the Deep South. By February 1861, he faced a stark choice: to remain in a Union controlled by radical Republicans or join the radical secessionists who advocated disunion. He also became convinced of the inevitability of war. In his letter to Douglas, he wrote that if he were "spared" he intended to write a history of the United States that explored "the causes which have contributed to the rise and the fall of the Republic." Written two days after the opening of the Montgomery Convention that created the Confederate States of American but two full months before Virginia seceded from the Union, the letter demonstrated Bledsoe's waning unionism. ${ }^{16}$ Bledsoe believed the secession crises resulted from human passions. In March 1848 , he had suggested the possibility that malignant human passions might one day undo the Union, but reassured his readers that they should not worry about such "gloomy forebodings" because the "liberties of man" were not "bound up in the fate of this republic." Although "the principles of liberty had been carried backward and forward, by the mutability and fluctuations of human passion," he reminded readers that they should trust that God had designed "an undercurrent of humanity" that carried the human race "onward in its slow but resistless progress." He asked his readers to consider the possibility that the American experiment, the contemporary pinnacle of civilization, 
might merely represent a step toward "more glorious developments of man's social nature." Lincoln's election with only northern support followed by the secession of the Deep South signified to Bledsoe that divine providence was guiding the South to a "more glorious development."17

Bledsoe had not supported states' rights before he concluded that secession represented the South's best option for securing liberty. As a result, his embrace of a centralized southern Confederạte state did not require a significant intellectual leap. Historians Elizabeth Fox-Genovese and Eugene D. Genovese portray the Deep South as a monolithic region in which slaveholders and non-slaveholders shared an attachment to "rural independence-including the light hand and limited intrusion of government, federal or state." These values, they argue, challenged Confederate nationalism. Many white southerners resented "the effects of centralization" and believed that a strong state contradicted "many of the principles that had justified their nation's existence in the first place." Historian Anne Sarah Rubin acknowledges the intellectual challenges confronted by the creators of Confederate identity but argues that southerners quickly overcame these difficulties. "The speed with which white Southerners, many of them staunch Unionists through the election of 1860 , shed their American identity and picked up a sense of themselves as Confederates, she notes "was startling." Mulling over the creation of the southern Confederacy in February 1861, Bledsoe had few qualms about a centralized state. His Whig vision of the world did not allow him to glorify rural independence. As a member of the Illinois Whig Party, Bledsoe eagerly advocated measures that required federal subsidies for internal improvements. He believed that governments were obligated to improve the nation economically and morally. The idea of 
a modern slaveholding republic appealed to Bledsoe because it promised to ensure the liberty of all white men while protecting an institution that recognized social hierarchies, protected the commonweal by ensuring public order, and promoted the improvement of the enslaved population. ${ }^{18}$

On February 4, representatives from the seven seceded southern states convened in Montgomery, Alabama. By February 8, they had officially adopted a constitution and created a new government. The events in Montgomery propelled Bledsoe further toward secession. His letter to Douglas reveals that he had given up hope for the republic in February; by March he became a vocal advocate for secession. Bledsoe's biographer Terry A. Barnhart challenges the image of Bledsoe as an "ardent secessionist," noting Bledsoe's political affiliation with the Constitutional Union Party and active support of Unionism in 1860. Barnhart suggests that Bledsoe did not embrace secession until shots were fired at Fort Sumter, Lincoln called up troops to put down the rebellion, and Virginia voted to secede on April 17. But Barnhart's account fails to recognize the significance and timing of Bledsoe's letter to Douglas. Although Bledsoe employed an emotional rhetorical style, he never entered into discussion of any political or intellectual matter without careful consideration. Certainly, he would not have made such emotional comments to a public figure like Douglas had his sentiments not been genuine. Moreover, Barnhart fails to consider how Bledsoe's University of Virginia students evaluated their professor's behavior during the secession crisis. ${ }^{19}$

On the morning of March 16,1861, the grounds at the University of Virginia witnessed a moment of tense excitement. The previous night, while the rest of Charlottesville slept, a group of secession-hungry students climbed atop the famed 
Rotunda, the university's centerpiece and most symbolic building, and replaced the flag of the United States of America with a secession flag. The bold act mirrored similar flagraising events at five other Virginia universities and represented one of the methods by which students, who eagerly embraced secession, defied their more conservative and unionist elders. As the students vacated their dormitories and morning lectures and gathered on the Lawn in the center of the Academical Village, Bledsoe, the chair of the mathematics department, intervened to prevent further disruption. When he ascended the steps of the Rotunda and turned to address the students, they gave him their attention. The students, who had become accustomed to Bledsoe's advocacy of secession during his mathematics lectures, must have been surprised by his request that they remove the flag. Bledsoe told the students that he did not doubt the character of the gentlemen who raised the flag, but he reminded them that Virginia had not yet decided to secede from the Union, even if "she ought to." The university was state property, and thus he warned that it was inappropriate to fly the banner. After the students began to comply with his request and order was restored, Bledsoe reassured the students of his secessionist sympathies by requesting they remove the banner "very tenderly.,"20

Students who recalled Bledsoe's speech that morning failed to record whether he acted at the request of the university's faculty or if he took it upon himself to defuse the situation. Given Bledsoe's deep-seated love of order, however, he likely took charge of his own accord. By March, Bledsoe had embraced secession. Still, as a man of conservative principles who considered actions that subverted engrained social hierarchies or threatened to upset public order anarchic, he hoped secession would occur with little fanfare and in an orderly, state-sanctioned, and what he considered a politically 
acceptable fashion. Because Bledsoe believed that the states had entered into the Union as a compact, he viewed secession as constitutional. None of the student's memoirs agreed on the exact date or precise wording of Bledsoe's speech but they all recounted that he expressed his support for secession and his admiration for the young men while encouraging them to act within the law. Shortly after the flag raising a group of students recounted the incident, in a letter to the Exchange. The young men described Bledsoe as "heartily endorsing the sentiments it manifested." Several of Bledsoe's students recalled the incident and other occasions when Bledsoe declared his support for secession. Sandie Pendleton juxtaposed Bledsoe's behavior during the flag raising incident with that of law professor and avowed Unionist John B. Minor. Upon seeing the flag, Minor lamented, "Flag of my county, can it be that in thy place a rag I see?" In contrast, Bledsoe stated that Virginia "ought" to secede. Randolph McKim, another Virginia student, labeled Minor a Union man and Bledsoe an "enthusiastic advocate of secession." McKim remembered that Bledsoe often "interlard[ed] his demonstration of some difficult problem in differential or integral calculus ... with some vigorous remarks in the doctrine of States' rights." These sources characterize Bledsoe as a secessionist by early March, joining the majority of his students who openly advocated secession long before Virgnia voted to secede. ${ }^{21}$

Historian Peter Carmichael argues that secession and the prospect of war offered young college-aged Virginians from slaveholding families an opportunity to display their manliness, an increasingly important consideration as the odds of becoming a successful planter diminished. Bledsoe and other Christian leaders influenced young Virginians via their participation in benevolent organizations such as the YMCA. They instilled in these 
young men the image of the Christian gentleman who also embraced an improvement ethic. As an ideal benevolent master, the Christian gentleman held dominion over those below him, including his wife, children, and slaves, but was never tyrannical. Instead, he ruled his family, white and black, with a firm but virtuous hand, keeping the interests of the whole in mind. Carmichael argues that "the idea of the Christian gentleman helped young Virginians negotiate between the aristocratic traditions of Virginia's slaveholding class and the bourgeois spirit of the times." With the majority of the arable land in Virginia already claimed, the state's sons rarely followed in their fathers's footsteps. Some young men chose to move westward and establish their own farms and plantations. But others sought to stay in Virginia and earn a living, often turning to careers in law or education. They retained the patriarchal image of the Christian gentleman but at the same time embraced the idea of diversifying Virginia's economy. They strived to hold on to Virginia's cultural heritage but they also "wanted the Old Dominion to become a leader in the age of progress." Bledsoe inculcated their forward looking vision of Virginia, and like them saw slavery and patriarchy as necessary elements in a progressive Old Dominion. During the secession crisis, young Virginians enthusiastically called for their state to secede from the Union and assume a place of leadership within the Confederacy. Their advocacy of disunion put them at odds with the majority of their father's generation. Bledsoe, in contrast, supported the younger men, but warned that their protests should stay within the bounds of the law. ${ }^{22}$

By February 1861, Bledsoe believed the Union doomed and hoped Virginia would secede and join the Confederate cause; nonetheless, his Whig love of order convinced him that secession should take place in an orderly legal manner. In the months 
before secession white southerners debated the legality of secession with "the great majority," concluding that states had a constitutional right to leave the Union. A minority, however, "appealed to the doctrine of resistance to tyranny as annunciated in their forefather's Declaration of Independence." Bledsoe certainly viewed the free power of the North as tyrannical but he did not appeal to the Declaration of Independence. As he later argued in Is Davis a Traitor?, Bledsoe believed that because the states had joined the Union as a compact, they retained the right to leave the compact at will. But Bledsoe had not supported states' rights before the secession crisis. In his 1841 eulogy honoring the life of President William Henry Harrison, Bledsoe praised the dead president for seeing himself as an American first and a Virginian second. He had noted that some Americans had a "regard for the state authorities ... so high and so exclusive, that they seldom fail to look upon the general government with an eye of jealousy and distrust." Harrison, in contrast, saw that "the rights of and the interests of the several states, and those of the nation at large, are mutually dependent upon each other for protection and support. There is no necessity for collision among them. The prosperity of the one is the prosperity of the other." While Bledsoe argued that a virtuous citizen should put the interests of the whole nation before the interests of his state, he believed that the nation had come together in the "spirit of mutual consent and forebearance," and could only be maintained through the same. ${ }^{23}$

The election of Lincoln symbolized to Bledsoe that the northern states no longer put the interest of the entire nation before their sectional concerns. For Bledsoe, the ability to place national interests above personal or sectional interests lay at the heart of liberty. In his eulogy for Harrison, Bledsoe wrote at length about the spirit of liberty and 
the American Revolution. He stressed that the "ruling spirit" of the Revolution was "sober, religious, determined and unconquerable. No local attachment, however strong; no private interest, however pressing; no prejudice of birth or education, no matter how inveterate; and no pride of opinion or theory, however indomitable, could divert it from a fixed and unalterable attachment to the good of the nation." In Bledsoe's mind, this spirit of liberty provided white men with "absolute equality of civil and religious rights." He believed that the North had lost sight of true liberty and imagined that the southern Confederacy could safeguard the values and continue the spirit of the American Revolution. Bledsoe remained committed to the idea that "better men" and "better institutions" would prevail. His teleological view of history allowed him to embrace the southern confederacy which would maintain a vision of social order and liberty that Bledsoe believed comported with the will of God. Bledsoe eagerly accepted a post in the C.S.A. War Department but his new country soon found another use for his unique talents. In 1863 , by a special request from Jefferson Davis, Bledsoe traveled to London and worked on a justification for secession, his research culminated in Is Davis a Traitor?, an apology that sought to legitimate secession as a constitutional right and affirm his belief that the southern states were the true inheritors of the American Revolution. $^{24}$

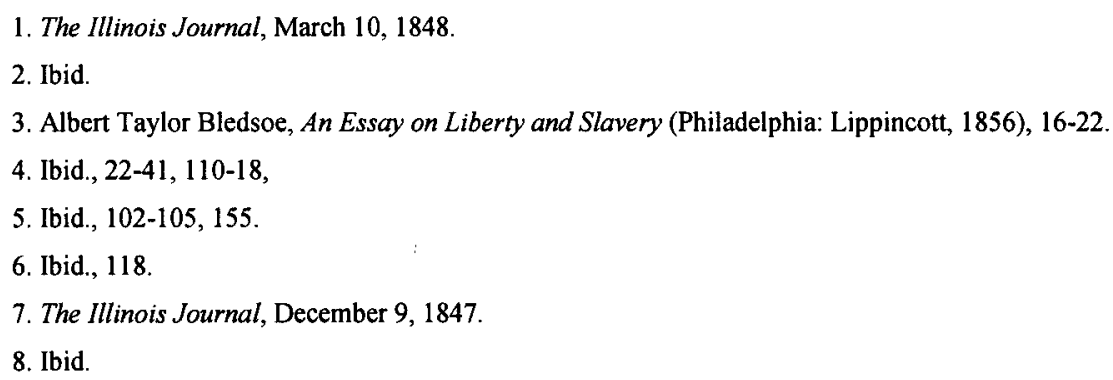


9. Daniel W. Crofts, Reluctant Confederates: Upper South Unionists in the Secession Crisis (Chapel Hill: The University of North Carolina Press, 1989), xvi-xxii.

10. Crofts, Reluctant, 68-71; Bledsoe, An Essay, 7, 129.

11. Crofts, Reluctant, 72-76.

12. Albert Taylor Bledsoe to Stephen A. Douglas, February 6, 1861, Stephen A. Douglas Papers, The Special Collections Research Center, University of Chicago.

13. Sean Wilentz, The Rise of American Democracy (New York: W. W. Norton \& Company, 2005), 755-58.

14. Crofts, Reluctant, 78.

15. Stanley Harrold, Border War: Fighting over Slavery before the Civil War (Chapel Hill: University of North Carolina Press, 2010), ix, 16, 196-201.

16. Samuel Willard, "Personal Reminiscences of Life in Illinois: 1830 to 1850," Transactions of the Illinois State Historical Society 11 (1906): 85-87; The Southern States (Okolona, Mississippi) December 10, 1877; Bledsoe to Douglas, February 6 , 1861 .

17. The Illinois Journal, March 10, 1848.

18. Elizabeth Fox-Genovese and Eugene D. Genovese, The Mind of the Master Class: History and Faith in the Southern Slaveholder's Worldview (New York: Cambridge University Press, 2005), 711-17; Anne Sarah Rubin, A Shattered Nation: The Rise and Fall of the Confederacy, 1851-1868 (Chapel Hill: University of North Carolina Press, 2005), 1-3.

19. Terry Barnhart, Albert Taylor Bledsoe: Defender of the Old South and Architect of the Lost Cause (Baton Rouge: Louisiana State University Press, 2011), 5-8; W. G. Bean, Stonewall's Man: Sandie Pendleton (Chapel Hill: University of North Carolina Press, 1959), 31-32; Randolph H. McKim, A Soldier's Recollections: Leaves from the Diary of a Young Confederate (New York: Longmans, Green, and Co., 1921), 1-3.

20. Peter S. Carmichael, The Last Generation: Young Virginians in Peace, War, and Reunion (Chapel Hill: University of North Carolina Press, 2005), 137-40. Carmichael names William and Mary, the Virginia Military Institute, Roanoke College, Lynchburg College, and Washington College as the five universities that raised secession flags prior to the start of the Civil War; Bean, Stonewall's Man, 31-32; McKim, A Soldier's, 1-3.

21. University of Virginia Students' Letter to the Editors of the Exchange, March 22, 1861, Accession \#15097, Special Collections University of Virginia Library, Charlottesville, VA; Walter Creigh Preston to John M. Preston, April 29, 1861, Virginiana, 1829-1909, Accesssion \#11143, Special Collections Dept., University of Virginia Library, Charlottesville, VA; Bean, Stonewall's Man, 31-32; McKim, A Soldier's Recollections, 1-3.

22. Carmichael, Last Generation, 10-13.

23. Fox-Genovese and Genovese, Mind, 614; Albert Taylor Bledsoe, Is Davis a Traitor; or was Secession a Constitutional Right Previous to the War of 1861 ? (Baltimore: Innes \& Company, 1866), 1-8.; The Illinois Journal, May 14, 1841.

24. The Illinois Journal, May 14, 1841. 


\section{CONCLUSION}

On April 9, 1865, Ulysses S. Grant and Robert E. Lee met in the parlor of Wilmer McLean at Appomattox Court House, Virginia. As Bledsoe's former West Point classmate discussed the terms of surrender with the Union general and effectively ended the Civil War, Bledsoe sat on the opposite side of the Atlantic composing Is Davis a Traitor? Finding the Confederacy defunct, Bledsoe took faith in his ability to demonstrate the right of secession. He spent the remainder of his life both vindicating secession and promoting the Confederate States of American as the Lost Cause in the pages of the Southern Review.

By the summer of 1863 , Bledsoe must have harbored some doubts about the Confederacy's future. Crushing defeats at Gettysburg and Vicksburg loomed in his mind when Jefferson Davis asked him to travel to London and work on a constitutional defense of secession. Still, Bledsoe yearned to serve his country. He had not flourished in the Confederate War Department. His inability to get along with Secretaries of War Judah P. Benjamin and George W. Randolph led to his early departure from the department. J. B. Jones, a clerk in the department, documented Colonel Bledsoe's frustrations. Bledsoe disliked the monotonous paperwork that accompanied his position. Within a week of being appointed by Davis as the chief of the bureau of war, Jones noted that "Col. Bledsoe has given up writing almost entirely, but he groans as much as ever. He is like a fish out of water, and unfit for office." The trip to London offered Bledsoe the opportunity to serve his country in a capacity more suited to his intellectual interests. 
Perhaps Bledsoe's failure as a Confederate official caused him to imbue his work in London with more gravity than it deserved. After visiting London, he cast himself as the Confederacy's great defender. ${ }^{1}$

In the autumn of his life, Bledsoe composed a memorandum of his personal letters that discussed his time in London and remarked on his notoriety among English elites. The memorandum reveals not only Bledsoe's inflated ego but also his sense of deep connection with the Confederate cause. Remarking on a letter from English Confederate sympathizer Louisa Tremlett, Bledsoe affirmed, "If the South should ever owe me anything for the vindication of her honor, and I know she will, she will owe it also to Miss Louisa Tremlett, to her mother, and to Mr. Tremlett." Bledsoe believed that he had not only vindicated the South's honor but that his intellectual prowess had saved the Confederacy's leader. Remarking on a letter from William B. Reed, attorney for Jefferson Davis, Bledsoe bragged, "When Davis begged me to publish the book, just before the time set for his trial, he said he knew that no one would analyze and discuss the subject as I had done." His time in London as ambassador and defender of the South confirmed Bledsoe as a stalwart son of the South. ${ }^{2}$

Bledsoe returned from London in 1866 and settled in Baltimore. A year later he took up the post as co-editor of the Southern Review. Through his writing in the quarterly Bledsoe earned the moniker of unreconstructed southerner. The pages of the Review also demonstrate the persistence of Bledsoe's conservative ideology, organic view of society, and his deep religious convictions. Historian George H. Nash argues that American conservatism defies definition but can be understood, in part, as resistant to what conservative-minded people consider subversive forces. Historian Patrick Allitt's 
similarly describes American conservatism as an attitude toward social and political change that places more faith in the past than in social and political innovation. Following these definitions, Bledsoe became even more conservative during the postbellum years. Rather than looking forward to a new republic to reverse the growing democracy and equalitarianism, Bledsoe pointed to the vaunted Confederacy as the last hope for the spirit of true liberty and equality. In his antebellum remarks on slavery, Bledsoe relied heavily on abstract political philosophy to demonstrate his arguments. In his 1871 essay on women's suffrage, however, Bledsoe appealed to both recent and deep history. He warned that women suffrage would further undermine social order and pointed to what he considered the horrors of black male suffrage. He also warned of social decay brought about by divorce and cited the fall of the Roman Empire to prove his point. His postwar political and social commentaries exhibited a deeper pessimism about the nation's future and were more conservative than his antebellum remarks. ${ }^{3}$

Bledsoe continued to believe that the preservation of social hierarchies represented the best safeguard against anarchy, chaos, and social disorder. Patrick Allitt argues that American conservatism is reactionary and responds to political and intellectual shifts. Bledsoe certainly demonstrates the reactionary nature of American conservatism. Because he believed that any threat to social order also represented a slight to the natural and moral order of the universe, he responded defensively to any perceived threats to natural hierarchies and social order. In the 1840s he interpreted Andrew Jackson and the Democrats as demagogues who threatened republican liberty. By the 1850 s, Bledsoe saw the abolitionists as the primary instigators of anarchy and disorder. During Reconstruction, Republicans took center stage in the drama for Bledsoe, 
becoming the ultimate demagogues. In his eyes, the party had thrust black male suffrage upon the nation and manipulated the mass of freedmen whom he believed lacked the mental capacity to vote. In Bledsoe's estimation, moreover, African Americans remained devoid of republican virtue. Thus, African American suffrage represented the biggest threat to natural hierarchy and social order. ${ }^{4}$

In the early 1840s, Bledsoe worked alongside Abraham Lincoln in Springfield's Whig Party in order to expose Jackson as a demagogue and show that the Democratic leadership, including Jackson, whom Bledsoe called King Demos, manipulated the mass of Democratic voters. In the postbellum years, Bledsoe directed these same charges against the Republicans and the deceased Lincoln. In commenting on Lincoln's position as the leader of the Republican Party, Bledsoe surmised that "no man [was] fitter than he, indeed, to represent the Northern Demos" in their "brute force, blind passion, fanatical hate, lust of power, and greed of gain, against the cause of constitutional law and human rights." Bledsoe dedicated many pages of the Southern Review to lambasting his former colleague as "low, ignorant, and vulgar." He accused Lincoln of having "ambitious designs" and noted that the president was skilled in the "scheming art of deception." Bledsoe even accused Lincoln of the most unthinkable crime, atheism. Lincoln, he charged, only embraced religion and God when it suited his needs or when God's providence mirrored his own ambitions. ${ }^{5}$

Although always a deeply religious man, Bledsoe leaned more heavily on his religious beliefs as politics failed him. Like other praying southerners, Bledsoe came to see the South's struggle as part of a grander cosmic plan and he considered it better to suffer in morality than to prosper in depravity. In his early writings he looked to political 
philosophy to answer questions about proper government. After the war, he concluded that all men were too depraved for self-government and self-interest doomed democratic governments. He argued that popular sovereignty would never work because it was premised on the faulty notion of man's inherent goodness. Throughout the last years of his life, the Southern Review took a decidedly religious turn. In part, the focus of the journal changed because financial straits forced Bledsoe to seek the support of the Methodist Conference. But Bledsoe continued to pen the majority of the articles for each issue and the shift toward a religious focus probably reflected his disgust with politics and his belief that the South was part of a larger cosmic struggle. ${ }^{6}$

However, Bledsoe was ultimately forced to revise his understanding of the cosmos. Bledsoe had always envisioned a cosmos in which science and religion were not only compatible but mutually reinforcing and he considered himself a great natural philosopher akin to the likes of Isaac Newton. But the ascendancy of Charles Darwin's theory of natural selection represented a blow to Bledsoe's view of the world and he could not reconcile his reading of the Bible with Darwin's evolutionary theory. In his review of On the Origin of Species, Bledsoe remarked that the naturalist's theory "clearly seems to conflict with the word of God, as well as the teachings of the wise and good in all ages; a theory, too, which annihilates the dignity of man, as well as obscures the glory of God." Bledsoe warned that readers should be cautious about accepting a "new-fangled hypothesis." He concluded that if mankind were to "pin our faith to any man's sleeve," it should be, "a Socrates, a Plato, a Pascal, a Bacon, a Butler, or a Newton rather than that of a Darwin or a Huxley." Bledsoe had based his understanding of the cosmos on the assumption that science and religion were intellectually consistent, and now his 
intellectual world was coming unraveled. Bledsoe died on December 8, 1877 in

Alexandria, Virginia, and was interred on the hallowed grounds of his beloved University

of Virginia. With Reconstruction ended, the quintessential unreconstructed southerner could rest in peace. ${ }^{7}$

'. J. B. Jones, A Rebel War Clerk's Diary at the Confederate States Capital (Philadelphia: J. B. Lippincott, 1866), 51.

${ }^{2}$. The list and memorandum of the letters Bledsoe commented on can be found in Albert Taylor Bledsoe Miscellany, Albert Taylor Bledsoe 1809-1877, University of Virginia Special Collections Library, Charlottesville, $\mathrm{Va}$.

${ }^{3}$. George H. Nash, The Conservative Intellectual Movement in American since 1945, 30 $0^{\text {th }}$ anniversary ed. (Wilmington, DE: ISI Books, 2006), xix. Patrick Allitt, The Conservatives: Ideas and Personalities Throughout American History (New Haven, CT: Yale University Press, 2009), 2-3.

${ }^{4}$. Ibid., 3.

5. The Southern Review VOL \#? (April 1873), 360-64.

6. Paula Cozort Renfro, "Albert Taylor Bledsoe," in American Magazine Journalists, 1850-1900, Sam G. Riley, ed. (Detroit: Gale Research, 1989), 61-62.

7. Renfro "Albert Taylor Bledsoe,".63; Albert Taylor Bledsoe, review of On the Origin of Species Southern Review 13 (October 1873), 9. 


\section{REFERENCES}

\section{PRIMARY}

1850 Mississippi State Census, Slave Schedule

1850 United States Census, Slave Schedules

1860 Virginia State Census, Slave Schedule

Albert Taylor Bledsoe Miscellany, University of Virginia Special Collections Library, Charlottesville, Va.

Albert Taylor Bledsoe Notebooks, 1863-1867, University of Virginia Special Collections Library, Charlottesville, Va.

Baltimore Episcopal Methodist

Bean, W. G. Stonewall's Man: Sandie Pendleton. Chapel Hill: University of North Carolina Press, 1959.

Blackford, Lancelot to his father, 23 November 1857 . Special Collections University of Virginia Library, Charlottesville, Virginia.

Bledsoe, Albert Taylor. An Essay on Liberty and Slavery. Philadelphia: Lippincott and Company, 1856.

An Examination of President Edwards' Inquiry into the Freedom of the Will. Philadelphia: H. Hooker, 1845.

Is Davis a Traitor?: or, Was Secession a Constitutional Right Previous to the War Of 1861? Baltimore: Innes and Company, 1866.

"The Mission of Women." Originally printed in Southern Review (October 1871). Read before the $63^{\text {rd }}$ Congress, $1^{\text {st }}$ session, August 18, 1913.

"Notices of Books." Southern Review 39 (July 1876): 222.

A Theodicy: or Vindication of the Divine Glory as Manifested in the Constitution and Government of the Moral World. New York: Carlton \& Phillips, 1854

Bledsoe, Albert Taylor to the Board of Trustees of Miami University, 25 July 1836. Miami University Archives. Oxford, Ohio.

Bledsoe, A. T. to the Board of Trustees of Miami University, 15 Sept. 1836. Miami University Archives. Oxford, Ohio. 
Bledsoe, Albert Taylor to Harriet Coxe Bledsoe, 8 May, 1837. Accession \#3461-a. Special Collections University of Virginia Library. Charlottesville, VA.

Bledsoe, Albert Taylor to Jefferson Davis, 21 September 1864. Letters of Albert Taylor Bledsoe, 1858-1875. Accession \#3461. Special Collections, University of Virginia Library, Charlottesville, VA.

Bledsoe, Albert Taylor to Stephen Douglas, 6 February 1861. Stephen A. Douglas Papers, Box 38, Folder 8. Special Collections Research Center, University of Chicago Library.

Bledsoe, Albert Taylor to W. H. McGuffey, 17 January 1837. The Walter Havighurst Special Collections Library, Miami University, Digital Collections, William Holmes McGuffey Family Papers.

Dunaway, Wayland Fuller. Reminiscences of a Rebel. New York: The Neal Publishing Company, 1913.

\section{Episcopal Recorder}

Ferguson, Adam. An Essay on the History of Civil Society. Dublin: Boulter Grierson, 1767.

Herrick, Sophia Bledsoe. "Albert Taylor Bledsoe." The Alumni Bulletin. Charlottesville: University of Virginia Faculty. Vol. 6 (May 1899): 1-6.

"Personal Recollections of My Father and Mr. Lincoln and Mr. Davis." Methodist Review Quarterly (April 1915): 666-679.

The Illinois Journal

Jones, J. B. A Rebel War Clerk's Diary at the Confederate States Capital. Philadelphia: J. B. Lippincott, 1866.

McKim, Randolph H. A Soldier's Recollections: Leaves from the Diary of a Young Confederate. New York: Longmans, Green and Co., 1921.

Preston, Walter Creigh to John Preston, 29 April 1861. Special Collections, University of Virginia Library, Charlottesville, VA.

Richmond Christian Advocate

The Sangamo Journal

The Southern Review 
United States Military and Naval Academies Cadet Records and Applications 1805-1908. "Register of Cadet Applicants, 1819-1867." No. 1 (1819-1827), West Point, Orange, New York.

University of Virginia Students' Letter to the Editors of the Exchange. March 22, 1861. Accession \#15097. Special Collections University of Virginia Library. Charlottesville, VA.

Virginia Historical Magazine 24 (1916), xxvi.

Walter Creigh Preston to John M. Preston. April 29, 1861. Virginiana, 1892-1909. Accession \#11143. Special Collections University of Virginia Library. Charlottesville, VA.

Willard, Samuel. "Personal Reminiscences of Life in Illinois: 1830-1850." Transactions of the Illinois State Historical Society, 6 (1906): 73-87.

\section{SECONDARY}

Allitt, Patrick. The Conservatives: Ideas and Personalities throughout American History. New Haven CT: Yale University Press, 2009.

Barnhart, Terry A. Albert Taylor Bledsoe: Defender of the Old South and Architect of the Lost Cause. Baton Rouge: Louisiana State University Press, 2011. "Albert Taylor Bledsoe: The Political Creed of an Illinois Whig, 1840-1848." Journal of Illinois History 3, no. 1, 2011:2-30.

Berlin, Ira. Many Thousands Gone: The First Two Centuries of Slavery in North America. Cambridge, MA: Harvard University Press, 1989.

Bynum, Victoria E. Unruly Women: The Politics of Social \& Sexual Conrol in the Old South. Chapel Hill: The University of North Carolina Press, 1992.

Carmichael, Peter. The Last Generation: Young Virginians in Peace, War, and Reunion. Chapel Hill: University of North Carolina Press, 2005.

Cooper, William J. Jr. The South and the Politics of Slavery, 1828-1856. Baton Rouge: Louisiana State University Press, 1978.

Crofts, Daniel W. Reluctant Confederates: Upper South Unionists in the Secession Crisis. Chapel Hill: The University of North Carolina Press, 1989.

Foner, Eric. Free Soil, Free Labor, Free Men: The Ideology of the Republican Party before the Civil War. Oxford: Oxford University Press, 1995. 
Fox-Genovese, Elizabeth and Eugene D. Genovese. Mind of the Master Class: History and Faith in the Southern Slaveholder's Worldview. New York: Cambridge University Press, 2005.

Goodheart, Adam. 1861: The Civil War Awakening. New York: Alfred A. Knoph, 2011.

Hatch, Nathan O. The Democratization of American Christianity. New Haven, CT: Yale University Press, 1989

Harrold, Stanley. Border War: Fighting over Slavery before the Civil War. Chapel Hill: University of North Carolina Press, 2010.

Holifield, E. Brooks. The Gentlemen Theologians: American Theology in Southern Culture, 1795-1860. Durham, NC: Duke University Press, 1978.

Holt, Michael F. Political Parties and American Political Development: From the Age of Jackson to the Age of Lincoln. Baton Rouge: Louisiana State University Press, 1992.

Howe, Daniel Walker. The Political Culture of American Whigs. Chicago: The University of Chicago Press, 1979.

What Hath God Wrought: The Transformation of America, 1815-1848. Oxford: Oxford University Press, 2007.

Irons, Charles F. The Origins of Proslavery Christianity: White and Black Evangelicals In Colonial and Antebellum Virginia. Chapel Hill: The University of North Carolina Press, 2008.

Johnson, Walter. Soul by Soul: Life inside the Antebellum Slave Market. Cambridge, MA: Harvard University Press, 1999.

Loveland, Anne C. Southern Evangelicals and the Social Order 1800-1860. Baton Rouge: Louisiana State University Press, 1980.

Morgan, Edmund S. American Slavery, American Freedom. New York: W.W. Norton \& Company, 1975.

Nash, George H. The Conservative Intellectual Movement in American since 1945, $30^{\text {th }}$ anniversary edition. Wilmington, DE: ISI Books, 2006. 
Pratt, Harry E. Albert Taylor Bledsoe: Critic of Lincoln. Springfield: Illinois State Historical Society, 1934.

Renfro, Paula Cozort. “Albert Taylor Bledsoe." In American Magazine Jouranlists, 1850-1900. Edited by Sam G. Riley. Detroit: Gale Research, 1989: 58-63.

Rodabaugh, James H. "A History of Miami University from its Origin in 1845." M. A. Thesis, Miami University, 1933.

"McGuffey: A Revised Portrait" The Oxford Criterion, 1934: 55-63.

Rubin, Anne Sarah. A Shattered Nation: The Rise and Fall of the Confederacy, 1861-1868. Chapel Hill, University of North Carolina Press, 2005.

Spencer, J. H. The History of Kentucky Baptists from 1769 to 1885, Vol. 1. Cincinnati: J. H. Spencer, 1886.

Tise, Larry E. A History of the Defense of Slavery in America, 1701-1840. Athens, GA: The University of Georgia Press, 1987.

Wilentz, Sean. The Rise of American Democracy. New York: W. W. Norton \& Co., 2005.

Wyatt-Brown, Bertram. Southern Honor: Ethics and Behavior in the Old South. Oxford Oxford University Press, 1982. 


\section{CURRICULUM VITAE}

NAME: $\quad$ Lori Jean Wilson

ADDRESS: $\quad 4117$ SW $20^{\text {th }}$ Ave.

\# 332

Gainesville, FL. 32607

DOB

Benton, Kentucky - May 26, 1974

EDUCATION: $\quad$ B.A. History

California State University Los Angeles

2010

AWARDS: $\quad$ Teaching Assistantship - University of Louisville, 2011-2012

Filson Historical Society Internship, 2010-2011

PUBLICATIONS: "Kissing Cousins: Legislating First Cousin Marriage in the

Progressive Era," Perspectives: A Journal of Inquiry 38 (2011), 92-109.

PROFESSIONAL

SOCIETIES: $\quad$ American Historical Association

Southern Historical Association 